2013

\title{
From the Particular to the General: Three Federal Rules and the Jurisprudence of the Rehnquist and Roberts Courts
}

Edward A. Purcell Jr.

New York Law School

Follow this and additional works at: http://digitalcommons.nyls.edu/fac_articles_chapters

\section{Recommended Citation}

162 U. Pa. L. Rev. 1731 (2013-2014)

This Article is brought to you for free and open access by the Faculty Scholarship at DigitalCommons@NYLS. It has been accepted for inclusion in Articles \& Chapters by an authorized administrator of DigitalCommons@NYLS. 


\section{ARTICLE}

FROM THE PARTICULAR TO THE GENERAL: THREE FEDERAL RULES AND THE JURISPRUDENCE OF THE REHNQUIST AND ROBERTS COURTS

\section{EDWARD A. PURCELL, JR. ${ }^{\dagger}$}

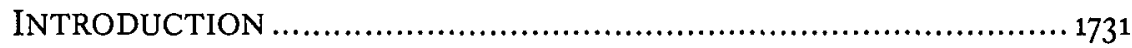

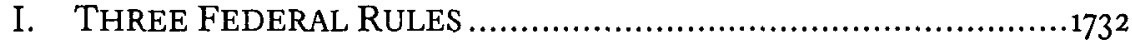

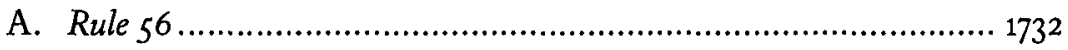

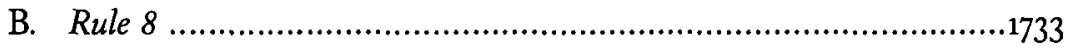

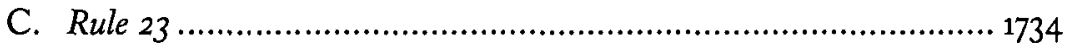

II. THREE COMMON CHARACTERISTICS .............................1735

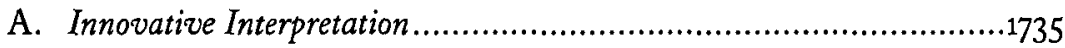

B. Practical Impact ...................................................... 1738

C. Social Congruence .................................................... 1742

III. “THE WHOLE OF THINGS" ....................................... 1747

A. Market Ideology ......................................................... 1749

B. Textualism, Originalism, and Traditionalism .............................. $175^{8}$

C. Judicial Ironies and "Living" Law ....................................... 1762

CONCLUSION.......................................................... 1764

\section{INTRODUCTION}

With the possible exception of John Marshall, the Justice most frequently quoted by legal scholars is almost certainly Oliver Wendell Holmes, Jr. Following that practice, I begin with an appropriate Holmesian injunction: our "business as thinkers is to make plainer the way from some thing to the whole of things." 1 Accordingly, the purpose of this Article is to suggest that

$\uparrow$ Joseph Solomon Distinguished Professor, New York Law School. The Author would like to thank Theodore Eisenberg, Stephen J. Ellmann, Brandt Goldstein, Lisa Grumet, Alfred S. 
recent Supreme Court decisions construing three Federal Rules of Civil Procedure "make plainer" some salient aspects of a particularly important "whole"-namely, the jurisprudence of the Rehnquist and Roberts Courts.

\section{THREE FEDERAL Rules}

\section{A. Rule 56}

In 1986, the Rehnquist Court decided three cases construing Rule 56 that encouraged motions for summary judgment and made it easier for defendants to prevail on these motions. ${ }^{2}$ Celotex Corp. v. Catrett allowed defendants to succeed at summary judgment without presenting evidence negating plaintiffs' allegations. ${ }^{3}$ Matsushita Electric Industrial Co. v. Zenith Radio Corp. required that plaintiffs' factual allegations meet a plausibility standard and thereby narrowed the reasonable inference rule favoring nonmoving parties. ${ }^{4}$ Finally, Anderson v. Liberty Lobby, Inc. imposed a higher evidentiary standard on plaintiffs alleging claims requiring "clear and convincing" proof and, in effect, gave courts the option to weigh plaintiffs' evidence and to find it insufficient to prevent summary judgment. ${ }^{5}$

Subsequently, in Scott v. Harris, the Roberts Court further widened the path to summary judgment by authorizing courts to weigh evidence in a broader range of cases and give dispositive credence to some items while dismissing others. ${ }^{6}$ In this case, the Court found that a videotape of the

Konefsky, Michael Perlin, and the members of the New York Law School Faculty Workshop for their helpful comments, and Michael McCarthy and Danae Kapralos for their research assistance.

1 Oliver Wendell Holmes, The Profession of the Law, in Collected Legal Papers 29. 30 (1921).

2 See generally Arthur R. Miller, The Pretrial Rush to Judgment: Are the "Litigation Explosion," "Liability Crisis," and Efficiency Clichés Eroding Our Day in Court and Jury Trial Commitments?, 78 N.Y.U. L. REV. 982 (2003) (discussing the impact of the "Supreme Court 'trilogy" of cases, Matsushita Electric Industrial Co. v. Zenith Radio Corp., Anderson v. Liberty Lobby, Inc., and Celotex Conp. v. Catrett, on the use of summary judgment).

3477 U.S. 317,325 (1986) (explaining that the moving party must point out only an absence of evidence supporting an essential element of the nonmoving party's case to succeed at summary judgment).

4475 U.S. 574, 595-97 (1986) (finding that petitioners' conduct did not give rise to an inference of conspiracy given that the evidence showed no "plausible" motive to engage in a conspiracy).

5477 U.S. 242,254 (1986) (holding that "in ruling on a motion for summary judgment, the judge must view the evidence presented through the prism of the substantive evidentiary burden" for the relevant claim).

6550 U.S. 372,380 (2007) ("When opposing parties tell two different stories, one of which is blatantly contradicted by the record[,] . . . a court should not adopt that version of the facts for purposes of ruling on a motion for summary judgment."). 
incident in question "blatantly contradicted" the plaintiff's testimony "so that no reasonable jury could believe" him. ${ }^{7}$ Compounding the already dubious nature of the Court's decision, a subsequent study found that a significant minority of people viewing the same videotape disagreed with the Court's interpretation, suggesting that the tape contained ambiguities that should have made the issue a jury question. ${ }^{8}$ Indeed, strengthening that conclusion, the study also showed that perceptions of the tape's significance varied by race, income level, and political and ideological commitments. ${ }^{9}$

\section{B. Rule 8}

Addressing Rule 8, and going well beyond the restrictive efforts of the Rehnquist Court, the Roberts Court substantially heightened pleading requirements in Bell Atlantic Corp. v. Twombly ${ }^{10}$ and Ashcroft v. Iqbal. ${ }^{11}$ As it had been understood since its adoption in 1938, Rule 8 embodied the basic principle of "notice pleading" that the Federal Rules established, and it required only "a short and plain statement" of a plaintiff's claim. Consequently, for almost half a century, the Court held that a complaint "should not be dismissed for failure to state a claim unless it appears beyond doubt that the plaintiff can prove no set of facts in support of his claim."12 Reinterpreting the rule and discarding precedent, Twombly and Iqbal now require plaintiffs to plead facts that show a "plausible" claim and promise a "reasonable" possibility of success. ${ }^{13}$

These decisions not only create a more demanding standard but also invite a relatively subjective application. Judges, Iqbal announced, should apply the higher standard by relying on their "judicial experience and common sense." 14 The subjective nature of the new test and its implicit

7 Id. at 380 .

8 Dan M. Kahan, David A. Hoffman \& Donald Braman, Whose Eyes Are You Going to Believe? Scott v. Harris and the Perils of Cognitive Iliberalism, 122 HARV. L. REv. 837, 864-66 (2009).

9 See id. at $867-70,879-80$ (finding that those individuals who disagreed with the Court "were connected by a core of identity-defining characteristics").

10550 U.S. $544(2007)$.

11556 U.S. 662 (2009).

12 Conley v. Gibson, 355 U.S. 41, 45-46 (1957); accord, e.g., Swierkiewicz v. Sorema N.A., 534 U.S. 506, 512 (2002) (referencing Conley for the proposition that Rule 8 establishes a "simplified notice pleading" standard intended only to give defendants "fair notice of what the plaintiff's claim is and the grounds upon which it rests" (quoting Conley, 355 U.S. at 47) (internal quotation marks omitted)); Leatherman v. Tarrant Cnty. Narcotics Intelligence \& Coordination Unit, 507 U.S. 163, 168 (1993) (holding that federal courts must apply Conley's liberal notice pleading standard to civil rights cases alleging municipal liability under $\S 1983$ ).

13 Iqbal, 556 U.S. at 678 ; Twombly, 550 U.S. at 557 .

14 Iqbal, 556 U.S. at 679 . 
invitation for courts to intrude even more deeply into jury functions are apparent: in both Twombly and Iqbal, the Court disregarded possible factual scenarios that would have made the defendants' actions unlawful. ${ }^{15}$ Strikingly, Iqbal rejected the "plausibility" of the plaintiffs' allegations simply because five of the nine Justices were willing to imagine "more likely explanations" for the defendants' behavior than the unlawful conspiracy that the plaintiff alleged. ${ }^{16}$

\section{Rule 23}

Finally, the Roberts Court made the requirements for certifying class actions under Rule 23 more demanding. Wal-Mart Stores, Inc. v. Dukes construed Rule 23(a) to impose on plaintiffs the burden of showing a significantly higher level of "commonality" in an identified class than previously required. ${ }^{17}$ Indeed, its method of analysis-probing proposed commonalities for every possible "dissimilarity" that could be teased outsuggested an approach designed to defeat a wide range of class actions at the certification stage.

The Court continued this trend in Comcast Corp. v. Behrend, which relied almost exclusively on Wal-Mart and declared that the "rigorous analysis" required under Rule $23(\mathrm{a})$ was similarly required under Rule $23(\mathrm{~b})(3) \cdot^{18}$ More restrictively, it held that the predominance requirement of Rule 23 (b)(3) could not be met unless plaintiffs could show that "damages are capable of measurement on a classwide basis" and then rejected the plaintiff's proposed methodology for calculating classwide damages as insufficiently "rigorous."19

15 See Arthur R. Miller, Simplified Pleading, Meaningful Days in Court, and Trials on the Merits: Reflections on the Deformation of Federal Procedure, 88 N.Y.U. L. REV. 286, 336 \& n.191 (2013) ("The Court's opinions in both Twombly and Iqbal offered innocent explanations for the defendants' conduct; these explanations were employed in a manner akin to judicial fact-finding." (citations omitted)).

16556 U.S. at 681.

$17{ }_{131}$ S. Ct. 2541, 2551 (2011) (explaining that commonality requires a "common contention ... capable of classwide resolution-which means that determination of its truth or falsity will resolve an issue that is central to the validity of each one of the claims in one stroke"). See generally A. Benjamin Spencer, Class Actions, Heightened Commonality, and Declining Access to Justice, 93 B.U. L. REV. 441 (2013) (discussing the restrictive commonality reasoning employed by the Court in Wal-Mart).

18 Comcast Corp. v. Behrend, 133 S. Ct. 1426, 1432 (2013).

19 Id. at 1433 (citing Wal-Mart, 131 S. Ct. at 2551-52) (internal quotation marks omitted). 


\section{THREE COMMON CHARACTERISTICS}

\section{A. Innovative Interpretation}

These decisions construing Rules 8,23 , and 56 share three common characteristics. The first is their highly questionable legal foundation. The decisions were not based on changes in the text of the rules or their original meanings. Although the Federal Rules have been amended on numerous occasions, the relevant standards in these three rules have never been substantively altered since their adoption.

The Court's 1986 trilogy of summary judgment decisions came almost a quarter of a century after Rule 56 had been last amended. These 1963 amendments made few changes to the rule and no revisions whatsoever in the standard it had established for granting summary judgment. ${ }^{20}$ Thus, the standard stood untouched when the Court issued its summary judgment trilogy in 1986, and no subsequent amendment altered that standard in a way that could justify Scott.

Similarly, the Roberts Court's decisions addressing Rules 23(a) and 23 (b)(3) construed language that had not been altered since its initial adoption in 1966. The 1966 amendments rewrote Rule 23(a) to identify characteristics that were "necessary but not sufficient" for class actions and reworked Rule 23 (b) to define additional conditions that justified three different types of class actions. ${ }^{21}$ One of the principal purposes of the amendments was to make the requirements for class actions less "abstract" and the class action form more widely available. ${ }^{22}$ Moreover, the Advisory Committee stated explicitly that, where "questions common to the class predominate," an action under subsection (b)(3) "may remain" as a class action "despite the need, if liability is found, for a separate determination of the damages suffered by individuals within the class." 23 Thus, contrary to the reasoning in Comcast, Rule $23(\mathrm{~b})(3)$ was not intended to require that damages calculations be part of the predominance requirement analysis.

When the 1966 amendments spurred an increasing number of class actions and gave rise to a variety of new problems, Rule 23 was altered to tighten

20 The standard for summary judgment appeared in subsection (c) from 1938 until 2010, when it was moved to subsection (a); the Committee Notes on Rules stated that the "standard for grariting summary judgment remains unchanged." See FED. R. CIV. P. 56(a) advisory committee's note to the 2010 amendments.

21 FED. R. CIV. P. 23(a) advisory committee's note to the 1966 amendments; see also A. Benjamin Spencer, supra note 17, at 450-51 (discussing the origins of Rule 23 and its new features).

22 FED. R. CIV. P. 23 advisory committee's note to the 1966 amendments.

23 FED. R. CIV. P. 23(b)(3) advisory committee's note to the 1966 amendments. 
some procedures and ensure greater fairness to class members. ${ }^{24}$ However, none of these post-1966 amendments changed the relevant text of subsections (a) and (b). Amendments in 1998 added certain interlocutory appeal provisions, ${ }^{25}$ and more substantial changes in 2003 modified subsections (c) and (e) and added new subsections ( $\mathrm{g}$ ) and (h). These latter amendments altered certain timing and notice provisions, deleted language authorizing conditional class certification, expanded the process for review of proposed settlements, and provided for more rigorous scrutiny of class counsel and attorneys' fees. ${ }^{26}$ However, none of these amendments altered the requirements of Rules $23(\mathrm{a})$ and $23(\mathrm{~b})(3)$.

Similarly, the Court's decisions redefining pleading standards under Rule 8 changed the meaning of a textual provision that had never been substantively altered. The few minor amendments to the rule made over the years were consistently identified as "technical" or "stylistic only."27

Two conclusions about the Court's recent decisions addressing Rules 8 , 23, and 56 are warranted. First, none of the decisions were based on any alterations in either the relevant text of the rules or their original meaning. Indeed, in imposing a plausibility requirement for pleadings, Twombly and Iqbal not only departed from the text and original understanding of Rule 8 but also rejected hundreds of years of legal practice defining the nature of the motion to dismiss for failure to state a claim. ${ }^{28}$ Second, the decisions departed from the Court's own precedents. ${ }^{29}$ Twombly was particularly

24 E.g., FED. R. CIV. P. 23 (2009); id. (2003); id. (1998).

25 See FED. R. CIV. P. 26 (f) advisory committee's note to the 1998 amendments (describing the addition of Rule ${ }_{23}$ (f) granting interlocutory appeals for class certification decisions).

26 See FED. R. CIV. P. 23(c) advisory committee's note to the 2003 amendments; see also Richard Marcus, Shoes That Did Not Drop, 46 U. MICH. J.L. REFORM 637, 641-44 (2013) (discussing the evolution of Rule 23 and the increasing attention Rule 23 garnered after class action litigation, especially asbestos mass tort litigation, became popular in the 1990s).

27 E.g., FED. R. CIV. P. 8 advisory committee's notes to the $1987 \& 2007$ amendments.

28 See Richard A. POSNER, HOW Judges THINK 53 (2008) ("[N]othing in the repertoire of legalism could have decided [Twombly], especially in favor of the position in the majority opinion...."); Miller, supra, note 15 , at 333-34 ("The Court essentially rewrote Rule 8 without anyone's assistance or any pretense of honoring the statutorily prescribed-and far more transparent and democratic-rulemaking process." (footnotes omitted)).

29 Compare Gen. Tel. Co. of Sw. v. Falcon, 457 U.S. 147, 157 (1982) (noting that a class of persons suffering the same injury as an individual will have claims that share common questions of law or fact with the individual's claim), and Adickes v. S.H. Kress \& Co., 398 U.S. 144, 159-60 (1970) (rejecting the argument that the nonmoving party must come forward with an affidavit asserting the fact relied on to avoid summary judgment), with Wal-Mart Stores, Inc. v. Dukes, 131 S. Ct. 2541, 2551 (2011) (citing Falcon for the proposition that commonality requires that the class members suffer the same injury), and Celotex Corp v. Catrett, 477 U.S. 317, 324 (1986) ("Rule 56(e) therefore requires the nonmoving party to go beyond the pleadings and by her own affidavits . . . designate 'specific facts showing that there is a genuine issue for trial.'). See generally 
blunt, dismissing the Court's long-established interpretation as nothing but "an incomplete, negative gloss" that was "best forgotten." 30 Arthur Miller concluded that the Court's decisions "essentially rewrote Rule 8" while "unilaterally 'rewriting' Rule 56 " and that "[n]othing in the language of Rule 23(a)(2), the provision's history, or prior jurisprudence justifies" the Court's conclusions in Wal-Mart. ${ }^{31}$

The changes the Court made in the construction of those rules, moreover, were particularly dubious because the Justices are bound by the Federal Rules as written and adopted.32 Indeed, the Rehnquist Court repeatedly acknowledged this structural separation-of-powers principle. Any change in Rule 8, it declared unanimously in 1993 , "must be obtained by the process of amending the Federal Rules, and not by judicial interpretation." 33 It reaffirmed that principle six years later when addressing class actions: "The nub of our position is that we are bound to follow Rule 23 as we understood it upon its adoption, and that we are not free to alter it except through the process prescribed by Congress in the Rules Enabling Act." ${ }^{34}$

Stephen B. Burbank, Vanishing Trials and Summary Judgment in Federal Civil Cases: Drifting Toward Bethlehem or Gomorrah?, 1 J. EMPIRICAL, LEGAL STUD. 591, 620 (2004) (noting that evidence suggests summary judgment became increasingly important in the 1970 s due to changes in the "nature and volume of federal litigation").

30 Bell Atl. Corp. v. Twombly, 550 U.S. 544, 563 (2007) (rejecting the rule of Conley v. Gibson, 355 U.S. 41 (1957)).

31 Miller, supra note 15 , at $333,310,319-20$. Many others agree. See, e.g., Twombly, 550 U.S. at 578 (Stevens, J., dissenting) (noting that the majority opinion "is the first by any Member of this Court to express any doubt as to the adequacy of the Conley formulation"); Matsushita Elec. Indus. Co. v. Zenith Radio Corp., 475 U.S. 574, 601 (1986) (White, J., dissenting) ("If the Court intends to give every judge hearing a motion for summary judgment in an antitrust case the job of determining if the evidence makes the inference of conspiracy more probable than not, it is overturning settled law."); Kevin M. Clermont \& Stephen C. Yeazell, Inventing Tests, Destabilizing Systems, 95 IOWA L. REV. 821, 832 (2010) ("[T]he Court's approach is thoroughly new.").

32 See Stephen B. Burbank, Procedure, Politics and Power: The Role of Congress, 79 NOTRE DAME L. REV. 1677, 1681-89 (2004) (describing the binding power of the Federal Rules and citing Mistretta v. United States, 488 U.S. 361, $386 \&$ n.14, 392 (1989), for the proposition that rulemaking is not a judicial power).

33 Leatherman v. Tarrant Cnty. Narcotics Intelligence \& Coordination Unit, 507 U.S. 163, 168 (1993).

34 Ortiz v. Fibreboard Corp., 527 U.S. 815, 861 (1999). See Catherine T. Struve, The Paradox of Delegation: Interpreting the Federal Rules of Civil Procedure, 150 U. PA. L. REV. 1099, 1119-20 (2002) (arguing that the rulemaking process serves as a constraint upon judicial interpretation that strays from the text of the Rules). 


\section{B. Practical Impact}

The second shared characteristic of the decisions construing these three Federal Rules is the practical social consequences they bring. All promise to discourage suits, burden plaintiffs, and defeat large numbers of claims. ${ }^{35}$ They also promise to defeat those claims more quickly and with much less cost to defendants. ${ }^{36}$

The Rule 56 decisions often relieve defendants of the need to present evidence, and they allow courts to evaluate the record more exactingly and deny the existence of "genuine" factual disputes more easily. ${ }^{37}$ They authorize courts to disregard and, in effect, weigh evidence and make subjective judgments as to both the "plausibility" of claims and the subjective motives of defendants. While the impact of the decisions has varied, evidence suggests that the trilogy significantly changed litigation practice in the lower federal courts and encouraged wider use of summary judgment. ${ }^{38}$ One study found that between 1975 and 2000 summary judgment motions in the federal courts nearly doubled and that courts granted them twice as often as they had in the past. ${ }^{39}$ Other studies have found that such motions have

35 Insofar as the rulemakers (in contrast to the Court) sought to limit allegedly "frivolous" suits and curb related litigation abuses, they attempted to do so by amending other rules. See, e.g., Bus. Guides, Inc. v. Chromatic Commc'ns Enters., 498 U.S. 533, $54^{2}$ (1991) (noting that "Rule 11 is 'aimed at curbing abuses of the judicial system'" (quoting Cooter \& Gell v. Hartmarx Corp., 496 U.S. 384, 397 (1990))); FED. R. CIV. P. 11 advisory committee's notes to the 1983 \& 1993 amendments (noting specifically that the amendments to Rule 11 were intended to reduce frivolous claims).

36 See Elizabeth M. Schneider \& Nancy Gertner, "Only Procedural": Thoughts on the Substantive Law Dimensions of Preliminary Procedural Decisions in Employment Discrimination Cases, 57 N.Y.L. SCH. L. REV. 767, 777 (2012-2013) (discussing the "pro-defendant heuristics" at play in these decisions); see also, e.g., Vance v. Ball State Univ., 133 S. Ct. 2434 (2013) (affirming the grant of defendant's motion for summary judgment in a Title VIl action). Despite the rhetoric of "litigation explosions," it is clear that the overwhelming majority of aggrieved individuals never take their claims to court. See FRANK A. SLOAN ET AL., SUING FOR MEDICAL MALPRACTICE 153 (1993) (noting that "only about a tenth of filed claims ever reach a courtroom"); David M. Engel, Perception and Decision at the Threshold of Tort Law: Explaining the Infrequency of Claims, 62 DEPAUL L. REV. 293, 334 (2013) (exploring some of the reasons why "the vast majority of injury cases" are disposed of "before the victim takes any action" in court).

37 E.g., Ricci v. DeStefano, 557 U.S. 557, 585-86 (2009) (citing Matsushita and Scott in granting summary judgment to plaintiffs challenging an affirmative action plan on the grounds that their adversary lacked a "strong basis in evidence to believe that it [would] be subject to disparateimpact liability" absent taking a race-conscious action).

38 David L. Shapiro, The Story of Celotex: The Role of Summary Judgment in the Administration of Civil Justice, in CIVIL PROCEDURE STORIES 359, 380 (Kevin M. Clermont ed., 2d ed. 2008).

39 See Joe S. Cecil et al., A Quarter-Century of Summary Judgment Practice in Six Federal District Courts, 4 J. EMPIRICAL \& LEGAL STUD. 861, 882-83 (2007) (finding an increase in the rate of 
been particularly effective in defeating employment discrimination, equal pay, and civil rights claims. ${ }^{40}$

Twombly and Iqbal proved even more effective in achieving anti-plaintiff results. First, they allow dismissal at an earlier stage, thereby freeing defendants from the need to mount a defense or even plead. Second, they require greater factual support and thereby place heavier burdens on plaintiffs before they even file suit. Third, they authorize a high degree of judicial discretion and encourage dismissals based on relatively subjective evaluations of the pleadings. Finally, and most restrictively, they require plaintiffs to plead facts before they have been able to obtain discovery. That requirement is especially likely to be fatal in the countless cases in which corporate and government defendants are in sole possession of critical evidence. After Twombly and Iqbal, motions to dismiss increased rapidly and succeeded more often. ${ }^{41} \mathrm{~A}$ recent study found that the two decisions "negatively affected" at least $15.4 \%$ of employment discrimination cases,

summary judgment motions made from $12 \%$ to $19 \%$ and an increase in cases terminated by summary judgment from $3.7 \%$ to $7.8 \%$ ).

40 See Kevin M. Clermont \& Stewart J. Schwab, Employment Discrimination Plaintiffs in Federal Court: From Bad to Worse? 3 HARV. L. \& POL'Y REV. 103, 128 n.68 (2009) (citing studies on summary judgment in employment discrimination cases); Bernice B. Donald \& J. Eric Pardue, Bringing Back Reasonable Inferences: $A$ Short, Simple Suggestion for Addressing Some Problems at the Intersection of Employment Discrimination and Summary Judgment, 57 N.Y.L. SCH. L. REV. 749, $75^{2}$ (2012-2013) (noting the frequency with which summary judgment is granted for defendants in employment discrimination cases); Deborah Thompson Eisenberg, Stopped at the Starting Gate: The Overuse of Summary Judgment in Equal Pay Cases, 57 N.Y.L. SCH. L. REV. 815, 821-24 (2012-2013) (identifying a similar phenomenon in Equal Pay Act cases); Nancy Gertner, Losers' Rules, 122 YALE L. J. ONLINE 109, 110-12 (2012) (explaining that federal courts were hostile to discrimination claims and use summary judgment to bring "prodefendant outcomes"); David L. Lee \& Jennifer C. Weiss, Inferences in Employment Law Compared to Other Areas of the Law: Turning the Rules Upside Down, 57 N.Y.L. SCH. L. REV. 781, 791-96 (2012-2013) (ascribing the trend toward summary judgment in employment cases to judges' insistence on drawing certain inferences in favor of the movant-employer and refusing to draw inferences in favor of the employee); Theodore Eisenberg \& Charlotte Lanvers, Summary Judgment Rates Over Time, Across Case Categories, and Across Districts: An Empirical Study of Three Large Federal Districts 28, 31, 33 (Cornell Law Sch. Legal Studies Research Paper Series, Research Paper No. 08-022), available at http://ssrn.com/ abstract $=1138373$ (higher summary judgment rates for civil rights cases).

41 JOE S. CECIL ET AL., FED. JUdiCIAL CTR., MOTIONS TO DISMISS FOR FAILURE TO STATE A ClAIM AFTER IQBAL: REPORT TO THE JUDICIAL CONFERENCE ADVISORY COMMITTEE ON CIVIL RULES 9-11, 14 (2011), available at http://ssrn.com/abstract=1878646; Patricia Hatamyar Moore, An Updated Quantitative Study of Iqbal's Impact on 12(b)(6) Motions, 46 U. RICH. L. REV. 603, 614 (2012) (finding an increase in the grant of 12 (b)(6) motions with leave to amend from $6 \%$ under Conley to $21 \%$ after Iqbal). See generally Alexander A. Reinert, Measuring Iqbal (unpublished manuscript) (on file with author) (noting the increased success of motions to dismiss after Twombly and Iqbal, particularly in civil rights cases). 
$18.1 \%$ of civil rights cases, and (excluding cases involving financial instruments) at least $21.5 \%$ of cases in other categories. ${ }^{42}$

Juxtaposing Celotex with Twombly and Iqbal, moreover, illustrates the purposeful nature of the Court's reasoning in seeking those results. In Celotex, the Court explained that there was a close relationship between Rules 8 and 56:

Before the shift to "notice pleading" accomplished by the Federal Rules, motions to dismiss a complaint or to strike a defense were the principal tools by which factually insufficient claims or defenses could be isolated and prevented from going to trial . . . . But with the advent of "notice pleading," the motion to dismiss seldom fulfills this function any more, and its place has been taken by the motion for summary judgment. ${ }^{43}$

Celotex reasoned, in other words, that summary judgment should be easier to obtain because "notice pleading" under Rule 8 had essentially eliminated dismissals for failure to state a claim. However, when Twombly and Iqbal subsequently made Rule 8 dismissals more readily available, the Court ignored the need it had stressed in Celotex for a balanced relationship between Rules 8 and $56 .{ }^{44}$ The Court did not suggest in either case the consequent need, in light of the newly expanded availability of Rule 8 dismissals, to re-rebalance the Federal Rules and return the summary judgment standard to its pre-trilogy level.

Finally, Wal-Mart and Comcast promise the same anti-plaintiff results under Rule 23. By imposing heavy evidentiary burdens on plaintiff classes, these cases require more substantial proof at an earlier stage and multiply the costs required to litigate in the class form. They promise to discourage and defeat large numbers of class actions, especially those brought by consumers and other large classes with relatively small individual claims. ${ }^{45}$

42 Jonah B. Gelbach, Note, Locking the Doors to Discovery? Assessing the Effects of Twombly and Iqbal on Access to Discovery, 121 YALE L.J. 2270, 2332 (2012). But see generally Lonny Hoffman, Twombly and Iqbal's Measure: An Assessment of the Federal Judicial Center's Study of Motions to Dismiss, 6 FED. CTS. L. REV. 1 (2011) (raising issues with the data relied on by Gelbach).

43 Celotex Corp v. Catrett, 477 U.S. 317, 327 (1986).

44 In 2002, a unanimous Court reaffirmed the principle that there was a balanced relationship between Rules 8 and 56. Swierkiewicz v. Sorema N.A., 534 U.S. 506, 513-14 (2002) (explaining that "[o]ther provisions of the Federal Rules of Civil Procedure are inextricably linked to Rule 8(a)'s simplified notice pleading standard," including Rules 12 and 56).

45 The Court did not raise the requirements for class certification in all of its decisions. See, e.g., Amgen Inc. v. Conn. Ret. Plans \& Trust Funds, 133 S. Ct. 1184, 1203-04 (2013) (holding that a district court need not consider rebuttal evidence at the class certification stage); Erica P. John 
Although both decisions are recent, class action defendants "have flooded courts with motions challenging discrimination and violation of labor laws." 46 In addition, a plaintiffs' class action law firm found that, by the end of 2012, "Wal-Mart ha[s] been cited a total of 541 times in lower court rulings, a remarkable figure for a decision rendered in June of 2011."47

Further, doubling down on its effort to defeat class actions, the Roberts Court held in $A T \mathcal{E}^{3} T$ Mobility $L L C$ v. Concepcion that corporations could deprive complainants of their right to bring class actions by imposing mandatory arbitration clauses in form contracts. ${ }^{48}$ By compelling customers and employees to arbitrate rather than allowing them to sue, corporations can deprive them of their day in court and force them into less desirable forums. Corporate defendants are often able to select arbitrators, limit discovery, ensure secrecy, minimize potential damages, and create de facto economic incentives for arbitration companies to favor their interests. In the two years since Concepcion, the courts have relied on arbitration clauses to dismiss more than a hundred consumer class actions. ${ }^{49}$

During the confirmation process, then-Judge John Roberts was asked whether he would support "the little guy" or "the big guy." He replied easily that he would simply ensure that "the Constitution and laws of the United States" determined who won..$^{50}$ Unfortunately, no one asked him whether he would try to see that "the little guy" could at least get "the big guy" into court so that the Constitution and laws could actually be applied to his claim.

Fund, Inc. v. Halliburton Co., 131 S. Ct. 2179, 2186-87 (2011) (holding that securities fraud plaintiffs need not prove "loss causation" at the class certification stage). Notably, however, in Amgen, four of the conservative Justices continued to press their effort to handicap plaintiffs and protect corporate defendants. Justice Alito suggested the desirability of reconsidering the fraudon-the-market theory of liability in actions for securities fraud, Amgen, 133 S. Ct. at 1204 (Alito, J., concurring), and Justice Scalia, id. at 1205-06 (Scalia, J., dissenting), and Justices Thomas and Kennedy, id. at 1206-07 (Thomas, J, dissenting), urged a more restrictive requirement for class certification in such actions.

46 Examination of Litigation Abuses: Hearing Before the Subcomm. on the Constitution E Civil Justice of the Comm. on the Judiciary, 113th Cong. 73 (2013) (statement of Joanne Doroshow, Executive Director, Center for Justice \& Democracy at New York Law School) (citation omitted).

47 SEyfarth Shaw LLP, ANNUAL WORKPLACE Class action Litigation RePORT 1 (2013), available at http://www.seyfarth.com/dir_docs/publications/CAR2013preview.pdf.

48 See generally ${ }_{131}$ S. Ct. 1740 (2011). The Court reaffirmed this ruling in American Express Co. v. Italian Colors Restaurant, 133 S. Ct. 2304 (2013).

49 See Examination of Litigation Abuses, supra note 46, at 71-72; see also Shauhin Talesh, How the "Haves" Come out Ahead in the Twenty-First Century, 62 DEPAUL L. REV. 519, 525-26 (2013) (emphasizing the inherent power imbalance in allowing companies to preclude class action suits and dictate the conflict resolution process).

50 Confirmation Hearing on the Nomination of John G. Roberts, Jr. to Be Chief Justice of the U.S.: Hearing Before the Comm. on the Judiciary, U.S. Senate, 109th Cong. 448 (2005). 


\section{Social Congruence}

The third characteristic that the decisions construing Rules 8,23 , and 56 share is their near perfect congruence with the practical social results that commonly flow from the decisions of the Rehnquist and Roberts Courts. ${ }^{51}$ In constitutional, statutory, and common-law matters, those Courts regularly burdened plaintiffs while protecting corporate $^{52}$ and governmental ${ }^{53}$ defendants. ${ }^{54}$

51 See generally Marcia COYLE, THe Roberts Court: THE STRUggle For THE CONSTITUTION (2013); Jan CRAWFORD GREENBURG, SUPREME CONFLICT: THE INSIDE Story of the StrugGle for Control of the United States Supreme Court (2007); Thomas M. Keck, The Most ACtivist Supreme Court in History: The ROAD TO MODERN JUdicial CONSERVATISM (2004); JEFFrey TOOBIN, THE Nine: INSIDE THE SECRET WORLD OF THE SUPREME COURT (2007).

52 See, e.g., Paul D. Carrington, Business Interests and the Long Arm in 2011, 63 S.C. L. REV. $6_{37}, 637$ (2012) (describing the Court as "captured by the Chamber of Commerce"); Lee Epstein, William M. Landes \& Richard A. Posner, How Business Fares in the Supreme Court, 97 MINN. L. REV. 1431, 1471 (2013) (highlighting the favorable treatment of businesses by the Roberts Court); A.E. Dick Howard, Ten Things the 2012-13 Term Tells Us About the Roberts Court, 99 VA. L. REV. 48, 52-54 (2013) (noting that the Supreme Court sided with the Chamber of Commerce, the representative of big business, in fourteen of eighteen cases in which the Chamber filed amicus briefs last year); Jeffrey Rosen, Supreme Court Inc., N.Y. TIMES (Mar. 16, 2008), http://www.nytimes.com/2008/03/16/magazine/16supreme-t.html (describing the Supreme Court as "surprisingly united in cases affecting business interests"). See generally ALAN B. MORRISON, SAVED BY THE SUPREME COURT: RESCUING CORPORATE AMERICA (2011).

53 While the Court protected governments against tort and civil rights claims, it treated governmental units much less favorably when they sought to enforce certain kinds of regulatory, civil rights, and pro-consumer laws or sought to implement affirmative action plans. See, e.g., Ricci v. DeStefano, 557 U.S. 557, 592-93 (2009) (finding a Title VII violation by a city when it invalidated promotional test results on the ground that test results had disparate racial impact); Parents Involved in Cmty. Sch. v. Seattle Sch. Dist. No. 1, 551 U.S. 701, 745-48 (2007) (invalidating a local school district desegregation plan which used race as a factor in student assignments designed to increase diversity); infra text accompanying notes 77-78.

54 This characteristic social pattern is not, of course, absolute or all-encompassing. Given different legal areas and different factual contexts, variations occurred due to the vast number of considerations that can affect judicial decisionmaking, as well as differences in outlook and assumptions among the conservative Justices. The Court's most conservative Justices, for example, opposed the Court's use of the Due Process Clause to limit punitive damages. See, e.g., State Farm Mut. Auto. Ins. Co. v. Campbell, 538 U.S. 408, 429-30 (2003) (Scalia, J., dissenting); id. (Thomas, J., dissenting). Similarly, the conservative bloc sometimes split in "tort reform" cases, e.g., Wyeth v. Levine, 555 U.S. 555 (2009), and in employment discrimination cases, e.g., Burlington Indust., Inc. v. Ellerth, 524 U.S. 742 (1998), and on occasion upheld plaintiff claims, e.g., Burlington N. \& Santa Fe Ry. Co. v. White, 548 U.S. 53 (2006). See generally MARK TUSHNET, IN THE BALANCE: LAW AND POLITICS ON THE ROBERTS COURT (2013) (distinguishing between rulings that seemed to reflect primarily legal considerations and those that seemed to reflect ideological considerations); Howard M. Wasserman, The Roberts Coun and the Civil Procedure Revival, 31 REV. LITIG. 313 (2012) (pointing out limits to the Court's ideological decisionmaking). 
Examples abound. ${ }^{55}$ The Rehnquist and Roberts Courts limited securities fraud actions, ${ }^{56}$ restricted suits against pharmaceutical companies, ${ }^{57}$ and construed the Federal Arbitration Act broadly to exclude plaintiffs from the courts. ${ }^{58}$ They deployed the Eleventh Amendment to bar actions against states and state agencies under the Fair Labor Standards Act and federal antidiscrimination laws, ${ }^{59}$ and they construed the Due Process Clause to limit the reach of long-arm statutes designed to protect consumers. ${ }^{60}$ Perhaps most arresting, Chief Justice Rehnquist used the Federal Judicial Conference to campaign against the Violence Against Women Act (VAWA) and shortly after its enactment joined the Court's four other conservative Justices in striking down the private cause of action it created. ${ }^{61}$

Many of the most restrictive decisions came in civil rights cases. Indeed, in 1989 , as soon as the appointments of Justices Scalia and Kennedy created a solid five-Justice conservative bloc, the Court issued a string of decisions ${ }^{62}$

55 See generally Andrew M. Siegel, The Court Against the Courts: Hostility to Litigation as an Organizing Theme in the Rehnquist Court's Jurisprudence, 84 TEX. L. REV. 1097 (2006), and compare the qualifications, emphasizing the role of ideology in the Court's decisionmaking, in Stephen B. Burbank and Sean Farhang, Litigation Reform: An Institutional Approach, 162 U. PA. L. REV. 1543 (2014).

56 See, e.g.; Morrison v. Nat'l Austl. Bank Ltd., 130 S. Ct. 2869 (2010) (limiting Securities Exchange Act of $1934 \S 10(\mathrm{~b})$ to domestic transactions); Cent. Bank of Denver, N.A. v. First Interstate Bank of Denver, N.A., 511 U.S. 164, 191 (1994) (precluding private action for aiding and abetting under $\S 10(\mathrm{~b})$ ); see also Stoneridge Inv. Partners, LLC v. Scientific-Atlantic, Inc., $55^{2}$ U.S. $148,166-67$ (2008) (similarly limiting the private right of action in Rule $10 \mathrm{~b}-5$ cases).

57 Pliva, Inc. v. Mensing, 131 S. Ct. 2567, 2581-82 (2011) (limiting company liability by holding that federal drug regulations preempt state law claims).

58 See generally, e.g., AT\&T Mobility LLC v. Concepcion, 131 S. Ct. 1740 (2011); Gilmer v. Interstate/Johnson Lane Corp., 500 U.S. 20 (1991); Rodriguez de Quijas v. Shearson/Am. Express Co., Inc., 490 U.S. 477 (1989); Shearson/Am. Express Co., Inc. v. McMahon, 482 U.S. 220 (1987).

59 See generally, e.g., Fed. Mar. Comm'n v. S.C. State Ports Auth., 535 U.S. 743 (2002) (broadening Eleventh Amendment immunity by holding that a suit by a federal agency is not a suit by the U.S. government); Alden v. Maine, 527 U.S. 706 (1999) (applying the Eleventh Amendment bar to a claim under the Fair Labor Standards Act brought in state court); Dellmuth v. Muth, 491 U.S. 223 (1989) (applying the Eleventh Amendment bar to claims under the Education of the Handicapped Act).

60 See J. McIntyre Mach., Ltd. v. Nicastro, 131 S. Ct. 2780, 2790-91 (2011) (finding that the Due Process Clause prohibited the exercise of jurisdiction based on a stream-of-commerce theory).

61 See United States v. Morrison, 529 U.S. 598, 627 (2000) (invalidating the civil remedy found in 42 U.S.C. $\S 13981$ ). See generally Judith Resnik, The Programmatic Judiciary: Lobbying, Judging, and Invalidating the Violence Against Women Act, 74 S. CAL. L. REV. 269 (2000) (documenting Justice Rehnquist's opposition to the VAWA).

62 See generally Patterson v. McLean Credit Union, 491 U.S. 164 (1989) (construing the phrase equal right "to make and enforce contracts" in 42 U.S.C. $\S 1981$ narrowly to exclude from coverage claims alleging on-the-job racial harassment); Lorance v. AT\&T Techs., Inc., 490 U.S. 900 (1989) (ignoring the disparate impact of a seniority system absent evidence of discriminatory intent); Martin v. Wilkes, 490 U.S. 755 (1989) (allowing white firefighters to challenge employment decisions taken pursuant to consent decrees intended to increase hiring and promotion of 
that appeared so consistent in their purpose and so driven by the votes and values of the new conservative majority that Congress felt compelled to respond with the Civil Rights Act of $1991 .{ }^{63}$ The statute reversed parts of several decisions, amended five separate civil rights statutes, and proclaimed its express purpose "to respond to recent decisions of the Supreme Court by expanding the scope of relevant civil rights statutes." ${ }^{64}$

Thereafter, shifting from frontal assault to somewhat less obvious Fabian tactics, the Rehnquist and Roberts Courts continued steadily to restrict the nation's civil rights laws. They barred or heavily burdened claims against local governments and government officials under 42 U.S.C. $\S 19833^{65}$ while expanding the immunities enjoyed by individual government officials. ${ }^{66}$ They sharply narrowed the reach of the civil rights conspiracy statute, ${ }^{67}$ heightened requirements for plaintiffs under Title VII of the Civil Rights Act of $1964^{68}$ and the Age Discrimination in Employment Act, ${ }^{69}$ restricted

black firefighters); Wards Cove Packing Co. v. Atonio, 490 U.S. 642 (1989) (imposing a higher burden on plaintiffs in establishing a prima facie case for employment discrimination), superseded by statute, Civil Rights Act of 1991, Pub. L. No. 102-166, 105 Stat. 1074, as recognized in Raytheon Co v. Hernandez, 540 U.S. 44 (2003); Price Waterhouse v. Hopkins, 490 U.S. 228 (1989) (holding that a defendant can overcome a gender discrimination claim by showing the same decision would have been made absent a consideration of gender). Two further cases decided in 1991 also seemed to follow the pattern. See EEOC v. Arabian Am. Oil Co., 499 U.S. 244 (1991) (finding that Title VII does not apply extraterritorially to U.S. firms employing Americans abroad); W. Va. Univ. Hosps. v. Casey, 499 U.S. 83 (1991) (precluding fee shifting for expert witnesses in civil rights cases).

63 See generally Kingsley R. Browne, The Civil Rights Act of 1991: A "Quota Bill," a Codification of Griggs, a Partial Return to Ward's Cove, or All of the Above," 43 CASE W. RES. L. REV. 287 (1993); Roger Clegg, Introduction: A Brief Legislative History of the Civil Rights Act of 1991, 54 LA. L. REV. 1459 (1994); Peter M. Leibold, Stephen A. Sola \& Reginald E. Jones, Civil Rights Act of 1991: Race to the Finish-Civil Rights, Quotas, and Disparate Impact in 1991, 45 RUTGERS L. REV. 1043 (1993).

64 Civil Rights Act of 1991, Pub. L. No. 102-166, §3(4), 105 Stat. 1071 (1991) (codified as amended at 42 U.S.C. $\S 1981$ (2012)).

65 See, e.g., Connick v. Thompson, ${ }_{131}$ S. Ct. 1350 (2011); Town of Castle Rock v. Gonzales, 545 U.S. 748 (2005); Gonzaga Univ. v. Doe, 536 U.S. 273 (2002); Bd. of the Cnty. Comm'rs of Bryan Cnty. v. Brown, 520 U.S. 397 (1997); McMillian v. Monroe Cnty., 520 U.S. 781 (1997); DeShaney v. Winnebago Cnty. Dep't of Soc. Servs., 489 U.S. 189 (1989). See generally Susan A. Bandes, The Lone Miscreant, the Self-Training Prosecutor, and Other Fictions: A Comment on Connick v. Thompson, 80 FORDHAM L. REV. 715 (2011) (tracing the declining utility of $\S 1983$ ).

66 See Brosseau v. Haugen, 543 U.S. 194, 199-201 (2004) (per curiam) (extending qualified immunity by tightening the particularized showing required to demonstrate "clearly established" law); Anderson v. Creighton, 483 U.S. 635,640 (1987) (requiring that "clearly established" law be demonstrated at a "particularized" level of generality such that a "reasonable official" would recognize that he was violating a constitutional right).

67 See Bray v. Alexandria Women's Health Clinic, 506 U.S. 263, 274-287 (1993) (heightening the requirements for stating a claim under 42 U.S.C. $\$ 1985(3))$.

68 See Univ. of Tex. Sw. Med. Ctr. v. Nassar, 133 S. Ct. 2517, 2534 (2013) (denying a retaliation claim by adopting a relatively stringent causation requirement); Vance v. Ball State Univ., 133 S. Ct. 2434, 2448, 2454 (2013) (denying liability by defining the term "supervisor" narrowly). 
remedies under both Title VI of the Civil Rights Act of $1964^{70}$ and Title IX of the Education Amendments of $1972,{ }^{71}$ and limited the awards available under the civil rights attorney's fees statute. ${ }^{72}$ They nearly extinguished the power of the federal courts to create implied causes of action based on federal statutes ${ }^{73}$ and severely curtailed their power to create causes of action under the Constitution itself. ${ }^{74}$ Finally, they narrowed the powers of Congress under $\S 5$ of the Fourteenth Amendment, prohibiting enforcement of civil rights statutes against states and state agencies. ${ }^{75}$

69 See Gross v. FBL Fin. Servs., Inc., 557 U.S. 167, 179-80 (2009) (ruling that a plaintiff must prove that age was a but-for cause of the adverse employment action under the Age Discrimination in Employment Act).

70 See Alexander v. Sandoval, 532 U.S. 275, 293 (2001) (finding no private right of action under $\S 602$ ).

71 See Gebser v. Lago Vista Indep. Sch. Dist., 524 U.S. 274, 290-93 (1998) (narrowing the private right of action available under Title IX of the Education Amendments of 1972).

72 See Buckhannon Bd. \& Care Home v. W. Va. Dep't of Health \& Human Res., $53^{2}$ U.S. 598,610 (2001) (ruling that the "catalyst theory" is an impermissible basis for awarding attorney's fees under the Fair Housing Amendments Act and Americans with Disability Act); Farrar v. Hobby, 506 U.S. 103, 115-116 (1992) (limiting attorney's fees when only nominal damages are awarded); W. Va. Univ. Hosps., Inc. v. Casey, 499 U.S. 83, 100-02 (1991) (constraining the ability to collect fees for expert witnesses).

73 See Stoneridge Inv. Partners, LLC v. Scientific-Atlantic, Inc., 552 U.S. 148, 166-67 (2008) (narrowing grounds for liability in claims under the implied private right of action found in SEC Rule 10b-5); Sandoval, 532 U.S. at 293 (holding that Title VI does not "create a freestanding private right of action to enforce regulations promulgated under $\S 602 ") ;$ Gebser, 524 U.S. at 292 (restricting grounds of liability for claims under Title IX's private right of action). Justice Scalia has repeatedly insisted that the federal courts are not "common law" courts with common law powers, e.g., Corr. Servs. Corp. v. Malesko, 534 U.S. 61, 75 (2001) (Scalia, J., concurring), and urged "the categorical position that federal private rights of action will not be implied," Thompson v. Thompson, 484 U.S. 174, 191 (1988) (Scalia, J., concurring in the judgment). He nonetheless viewed the federal courts as sufficiently "common law" courts to allow them to create judge-made defenses against tort suits, Boyle v. United Techs. Corp., 487 U.S. 500, 515 (1988), and to invoke common law principles to trump statutory policy and limit claims under $\S 1983$, Heck v. Humphrey, 512 U.S. 477, 486-90 (1994); Newton v. Rumery, 480 U.S. 386, 392 (1987).

74 See Ashcroft v. al-Kidd, 131 S. Ct. 2074, 2089 (2011) (denying a Fourth Amendment claim for arrest and detention based on allegedly pretextual reasons and without probable cause); Wilkie v. Robbins, $55^{1}$ U.S. 537, 567-68 (2007) (denying a Bivens claim in spite of allegedly repeated abusive tactics by federal agents); Malesko, 534 U.S. at 74 (denying a Bivens claim against a private corporation operating a correctional facility under a contract with the Federal Bureau of Prisons); Schweiker v. Chilicky, 487 U.S. 412,429 (1988) (denying a Bivens claim and outlining an analysis that sharply restricted the availability of other such claims); United States v. Stanley, 483 U.S. $669,685-86$ (1987) (denying a Bivens claim against the U.S. Army even though the U.S. Army had knowingly and intentionally deceived the plaintiff, an enlisted person, who was allegedly seriously injured as a result).

75 See Bd. of Trs. of the Univ. of Ala. v. Garrett, 531 U.S. 356, 374 (2001) (denying a claim under the Americans with Disabilities Act brought against a state institution); Kimel v. Fla. Bd. of Regents, 528 U.S. 62, 91-92 (2000) (dismissing a claim under the Age Discrimination in Employment Act as prohibited by the sovereign immunity of states); Fla. Prepaid Postsecondary Educ. 
The majority's defenders contend that those decisions flowed from constitutional principles mandating strict limits on federal judicial power. The problem with that defense, however, is that the Court's use of the judicial power has been consistent mainly in its social results but not in any principled practice of "restraint" or deference to other levels and branches of government. Most commonly, the Rehnquist and Roberts Courts found their judicial limitation principles applicable when asked to uphold claims of consumers, employees, tort victims, environmentalists, and civil rights plaintiffs. For these claims, they portrayed the judicial power as largely or wholly impotent. ${ }^{76}$ Just as often, however, when the Rehnquist and Roberts Courts were asked to protect certain other interests, they ignored their principles of judicial limitation and exercised their power actively and robustly. ${ }^{77}$ They used their power to strike down numerous state and federal enactments, insulate state and local governments from damages suits, restrict or invalidate local affirmative action plans, limit congressional power and deny plaintiffs standing under Article III, conjure from whole cloth common law defenses for military contractors, and create novel constitutional rights protecting gun dealers and owners. ${ }^{78}$ Most striking, they used

Expense Bd. v. Coll. Sav. Bank, 527 U.S. 627, 647-48 (1999) (ruling that the federal Patent Remedy Act "cannot be sustained under $\S 5$ of the Fourteenth Amendment" in an action brought against a state institution).

76 See e.g., Judith Resnik, Constricting Remedies: The Rehnquist Judiciary, Congress, and Federal Power, 78 IND. L.J. 223, 308-10 (2003) (discussing how the Rehnquist Court constricted federal judicial remedy powers and how "the judiciary itself bec[ame] seen as a political institution").

77 During the 1990s, "the Rehnquist Court voided actions taken by states in $54.7 \%$ of the relevant cases it decided (111 of 203), an invalidation rate that was slightly higher than the Warren Court's rate of $53.6 \%$ in such cases during its sixteen years of existence (128 of 239)." Edward A. Purcell, Jr., The Courts, Federalism, and the Federal Constitution, 1920-2000, in 3 THE CAMBRIDGE History OF LAW IN AMERICA: THE TWENTIETH CENTURY AND AFTER (1920-) 127, 172 (Michael Grossberg \& Christopher Tomlins, eds., 2008).

78 See, e.g., Ruth Colker \& James J. Brudney, Dissing Congress, 100 MICH. L. REV. 80, 105-07 (2001) (arguing that the Rehnquist Court was not as solicitous of states' rights as often claimed and that it actively invalidated laws passed by Congress); Ruth Colker \& Kevin M. Scott, Essay, Dissing States?: Invalidation of State Action During the Rehnquist Era, 88 VA. L. REV. 1301, 1368-72 (2002) (arguing that the conservative Justices invalidated many state laws and followed similar, yet nuanced, patterns of voting on issues involving state powers in criminal law, religion, and freedom of speech cases); Howard, supra note 52, at 51, 52-54 (noting that the Roberts Court displays certain trends, such as an affinity toward big business, a "skepticism" toward affirmative action, and a willingness to engage in judicial activity in particularly ideological cases); Rorie Spill Solberg \& Stefanie A. Lindquist, Activism, Ideology, and Federalism: Judicial Behavior in Constitutional Challenges Before the Rehnquist Court, 1986-2000," 3 J. EMPIRICAL LEGAL STUD. 237, 254 (2006) (finding that "[a]ll the justices who significantly deviate from the Court do so in the direction predicted by their ideology"); Geoffrey R. Stone, The Behavior of Supreme Court Justices When Their Behavior Counts the Most: An Informal Study, 97 JUDICATURE 82, 83-84 (2013) (finding that ideological influences affect Supreme Court Justices more frequently in significant constitutional 
their judicial power audaciously in ways that promised to entrench the Republican Party: invalidating restrictions on electoral spending, clearing the way for widely recognized and methodical voter suppression efforts, and installing a Republican in the White House by prematurely terminating a presidential election. ${ }^{79}$

The decisions of the Rehnquist and Roberts Courts construing Rules 8, 23, and 56 stand prominently in the "boldness for business" half of that jurisprudential divide. First, they exemplify the willingness of the conservative Justices to use the judicial power aggressively, for those decisions essentially rewrote rules that Congress had authoritatively adopted and that the Court itself had previously construed differently. Second, they exemplify the conservative Justices' typical assertion of activist and robust judicial power when the result is to constrain or defeat tort, employee, consumer, antitrust, environmental, and civil rights plaintiffs.

\section{III. "ThE WhOLE OF THINGS"}

The three common characteristics of the Court's decisions construing Rules 8, 23, and 56-their break from established interpretations, their tendency to bring similar social results, and the congruence of those results with the characteristic social results of the Court's decisions in other areassuggest that a common inspiration links those Federal Rules decisions not only with one another but also with much of the jurisprudence of the Rehnquist and Roberts Courts.

That common inspiration cannot simply be the perceived desirability of reducing litigation costs, limiting the federal caseload, or addressing the genuine difficulties that class actions present. ${ }^{80}$ While those considerations

cases relating to issues such as voter enfranchisement, gun control, and abortion, than in other cases). See generally KECK, supra note 51.

79 See McCutcheon v. Fed. Elec. Comm'n, No. 12-536, slip op. at 39-40 (U.S. Apr. 2, 2014) (invalidating a federal statute that imposed aggregate limits on campaign contributions); Shelby Cnty. v. Holder, 133 S. Ct. 2612, 2649-50 (2013) (invalidating $\S 4$ (b) of the Voting Rights Act, which dictated the formula for the preclearance requirement, on the basis that the requirement was no longer necessary in today's social environment); Citizens United v. Fed. Elec. Comm'n, 558 U.S. 310, 368-72 (2010) (holding unconstitutional a federal statute that restricted corporate spending in political elections); Bush v. Gore, 531 U.S. 98, 109-11 (2000) (invalidating the Florida Supreme Court's decision to hold manual recounts of the state's votes in the 2000 presidential election).

80 See generally A. Benjamin Spencer, Essay, The Restrictive Ethos in Civil Procedure, 78 GEO. WASH. L. REV. 353 (2010) (discussing the Court's restrictive approach to procedural issues, which frustrates many claimants' attempts to have their cases tried on the merits). For more information on some of the special complications of class actions, see Richard Marcus, Still Confronting the Consolidation Conundrum, 88 NOTRE DAME L. REV. 557 (2012). 
are relevant, they are inadequate to explain the Court's decisions. First, any effort to change rules controlling access to the federal courts necessarily involves an assessment of social consequences, including which types of claims and litigants will be advantaged and which will be disadvantaged. ${ }^{81}$ Thus, the general goal of limiting the federal caseload, however warmly embraced, can never be adequate to determine which specific limitations should be adopted. That determination requires some additional criterion or a more specific goal. Second, while every member of the Court is sensitive to docket pressures and has supported measures designed to limit the federal caseload, ${ }^{82}$ the Justices have regularly disagreed as to many specific measures. The decisions of the Rehnquist and Roberts Courts construing Rules 8, 23, and 56-and most of their other anti-plaintiff decisions-have, in fact, been largely and often exclusively the product of the Court's conservative majority. Thus, the conservative majority is responsible for selecting the particular kinds of limitations the Court has imposed, and the choice of those particular limitations cannot be explained by a general policy of limiting the federal caseload.

Indeed, in Exxon Mobil Corp. v. Allapattah Services, Inc., the conservative Justices cast a bright and revealing light on their views about how much weight should be given to the goal of docket limitation. ${ }^{83}$ In that case, they gave an expansive interpretation to the supplementary jurisdiction statute ${ }^{84}-$ whose provisions could readily and fairly have been construed far more narrowly-and thereby stretched federal jurisdiction more widely over state law issues and opened the federal courts to large numbers of complex state

81 See generally Edward A. Purcell, Jr., The Class Action Faimess Act in Perspective: The Old and the New in Federal Jurisdictional Reform, 156 U. PA. L. REV. 1823 (2008).

82 See, e.g., Gunn v. Minton, 133 S. Ct. 1059, 1068-69 (2013) (unanimous) (holding that certain actions involving patents could be brought in state court and were not within the exclusive jurisdiction of the federal courts); Pearson v. Callahan, 555 U.S. 223, 243-45 (2009) (unanimous) (allowing lower courts to dismiss civil rights claims against government officials on qualified immunity grounds without ruling on the merits of the claims); Van de Kamp v. Goldstein, 555 U.S. 335, 348-49 (2009) (unanimous) (holding that heads of prosecutors' offices could be held liable only for failure-to-train or failure-to-supervise claims on exceptionally narrow grounds); Sinochem Int'l Co. v. Malaysia Int'l Shipping Corp., 549 U.S. 422, 436 (2007) (unanimous) (holding that a district court is not required to establish its own jurisdiction before it dismisses a lawsuit for forum non conveniens); Grable \& Sons Metal Prods., Inc. v. Darue Eng'g \& Mfg., 545 U.S. $308,319-20$ (2005) (unanimous) (tightening the requirements for a state-law claim involving federal law issues to come within federal question jurisdiction). See generally JOHN ROBERTS, 2012 YEAR-END REPORT ON THE FEDERAL JUDICIARY, available at http://www.supremecourt.gov/ publicinfo/year-end/2012year-endreport.pdf (showing smaller Supreme Court dockets in recent years).

83545 U.S. 546 (2005).

84 For the text of the supplementary jurisdiction statute, see 28 U.S.C. $\S 1367$ (2012). 
law cases ${ }^{85}$ The decision not only conflicted with the goal of docket limitation but also contradicted the conservatives' frequently proclaimed principles that purportedly demanded limitations on federal jurisdiction and greater respect for state courts and state sovereignty. Although puzzling in terms of doctrine and inconsistent in terms of their avowed principles, the conservatives' action was fully consistent with their substantive social policies. The interpretation they adopted promised to defeat class actions by allowing defendants to remove them to the relatively unfavorable national courts. Thus, Allapattah-by expanding rather than contracting federal jurisdiction in this particular context-served the same substantive social policy goals that inspired the Court's anti-plaintiff decisions in Wal-Mart, Comcast, and Concepcion. ${ }^{86}$

\section{A. Market Ideology}

Since the 1970 s market ideologies have grown increasingly prominent among American conservatives and within the ranks of the Republican Party. ${ }^{87}$ Those ideologies are powerful because they meld a number of

85 Exxon Mobil, 545 U.S. at $57^{1-72}$.

86 Allapattah made a jurisdictional change that achieved what congressional Republicans and business interests had been urging for a decade and one that they finally succeeded in enacting into law the very same year. Like Allapattah, the Class Action Fairness Act of 2005 (CAFA), Pub. L. No. 109-2, 119 Stat. 4 (2005), expanded federal jurisdiction over class actions raising state law claims and thereby promised to draw more of them into the federal courts, which had become increasingly hostile to class actions since the mid-1990s. Revealingly, Republican male judges in the lower federal courts subsequently applied CAFA with particular vigor to restrict class actions. For a review of a study reflecting these results, see Kevin M. Clermont \& Theodore Eisenberg, CAFA Judicata: A Tale of Waste and Politics, 156 U. PA. L. REV. 1553, 1585-86 (2008).

87 See generally PRESIDENT'S COUNCIL ON COMPETITIVENESS, AGENDA FOR CIVIL JUSTICE REFORM IN AMERICA (1991) (Bush administration) (suggesting restrictive reforms to the civil litigation system in order to limit costs and burdens); AM. TORT REFORM FOUND., JUDICIAL HELLHOLES (2007), available at http://www.judicialhellholes.org/wp-content/uploads/ 2010/12/jh2007.pdf (criticizing excessive tort liability and highlighting jurisdictions that allegedly hand out excessive plaintiff awards in personal injury suits); DEP'T OF JUSTICE, REPORT OF THE TORT POLICY WORKING GROUP ON THE CAUSES, EXTENT AND POLICY IMPLICATIONS OF THE CURRENT CRISIS IN INSURANCE AVAILABILITY AND AFFORDABILITY (1986) (Reagan administration) (suggesting limitations on tort liability to address an alleged liability insurance crisis); Memorandum from Lewis F. Powell, Jr. to Eugene B. Sydnor, Jr., Chairman, Educ. Comm., U.S. Chamber of Commerce (Aug. 23, 1971), available at http://law.wlu.edu/ deptimages/Powell\%20archives/PowellMemorandumTypescript.pdf (explaining dangerous threats that tort liability posed to the free market economy in the United States). For general treatments of the prominence of market ideologies in the conservative legal movement, see DONALD T. Critchlow, The Conservative Ascendancy: How the GOP Right Made Political History (2007) and STEven M. TEles, The Rise of THE Conservative LEGAL MOVEMENT: THE BATTLE FOR CONTROL OF THE LAW (2008). 
diverse but often interrelated social values and assumptions that justify a range of partisan policies under the banner of a heralded "common good." 88 They scorn and often wholly reject government economic regulation, and they encourage a true believer's faith in the operation of a near-perfect "free market" and the social benevolence of supposedly "rational" market behavior. ${ }^{89}$ These ideologies preach that efforts to impose burdens and liabilities on business are inefficient and that litigation against business wastes resources, destroys jobs, stalls the economy, and raises consumer prices. Implicit, and sometimes explicit, are the familiar counterposed assumptions of the worthy and unworthy: individuals who are able, honest, moral, and hard-working against those who are lazy, foolish, undisciplined, or immoral. Market ideologies assume that the former earn their livelihoods by hard work while pursuing the world's fair and ample opportunities for economic success; they assume that the latter seek to live off the work of others, exploit overly generous social welfare programs, and pursue "frivolous" lawsuits in the meretricious search for free riches. Among the most designing advocates of those market ideologies are the forces behind the "tort reform" movement, which is a well-financed and well-organized campaign to protect business interests by restricting judicial remedies, imposing heavy burdens on claimants, and limiting or denying access to the courts. ${ }^{90}$ Ultimately, those market ideologies lend themselves to justifying

88 For a general overview of how market ideologies can mix social values to validate partisan policies, see JOSEPH CRESPINO, IN SEARCH OF ANOTHER COUNTRY: MISSISSIPPI AND THE CONSERVATIVE COUNTERREVOLUTION (2007); JOSEPH CRESPINO, STROM THURMOND'S AMERICA (2012); GEOFFREY KABASERVICE, RULE AND RUIN: THE DOWNFALl OF MODERATION AND THE DESTRUCTION OF THE REPUBLICAN PARTY: FROM EISENHOWER TO THE TEA PARTY (2012); ROBERT O. SELF, ALL IN THE FAMILY: THE REALIGNMENT OF AMERICAN DEMOCRACY SINCE THE 1960S (2012); ROBERT O. SELF, AMERICAN BABYLON: RACE AND THE STRUGGLE FOR POSTWAR OAKLAND (2003).

89 It is essential to distinguish contemporary "market ideologies"-sweeping, uncompromising, and intensely partisan-from professional economic analyses of markets, which are careful, nuanced, qualified, and often highly skeptical of market behavior. See generally ALBERT O. Hirschman, The Passions and the InTerests: Political arguments For CAPITALISM BEFORE ITS TRIUMPH (1977) (explaining the rise of capitalism and exploring biases and inconsistencies in "market" reasoning); JOSEPH E. STIGLITZ, GLOBALIZATION AND ITS DISCONTENTS (2002) (examining the imperfections in the "market forces" behind globalization and suggesting appropriate reforms); JOSEPH E. STIGLITZ, THE PRICE OF INEQUALITY (2012) (arguing that income in the United States does not accurately track productive contribution to society and explaining the inefficiencies in market institutions).

90 See, e.g., William Haltom \& Michael MCCANN, Distorting the LAW: POLITICS, MEDIA, AND THE LITIGATION CRISIS 35-38 (2004) (explaining tort reform background and the history behind the tort reform movement); Theodore Eisenberg, U.S. Chamber of Commerce Liability Survey: Inaccurate, Unfair, and Bad for Business, 6 J. EMPIRICAL LEGAL STUD. 969, 971-76 (2009) (illustrating the misleading nature and "flawed methodology" of the U.S. Chamber of 
economic exploitation, social inequality, and systemic disregard for the poor, weak, powerless, disadvantaged, and disorganized. ${ }^{91}$ Indeed, exhibiting wondrous flexibility, such market ideologies can be adroitly contoured to justify almost anything that serves the interests of powerful economic groups.

Those market ideologies and "tort reform" goals call for exactly the kind of rulings that the Rehnquist and Roberts Courts have typically supplied. They are consistent with their decisions construing Rules 8, 23, and 56, as well as their decisions addressing many constitutional, statutory, and common law issues. Those ideologies and goals seem a common inspiration that helped shape the jurisprudence of the Rehnquist and Roberts Courts and produced the cornucopia of anti-plaintiff decisions that flooded the doctrinal landscape. 92

Commerce's Survey of State Liability and tort reform claims); Edward A. Purcell, Jr., Geography as a Litigation Weapon: Consumers, Forum-Selection Clauses, and the Rehnquist Court, 40 UCLA L. REV. 423, 498-510 (1994) (describing the use of forum-selection clauses as a "tort reform" tool to handicap consumers); Purcell, supra note 81, at 1889-1912 (describing the "Modern 'Tort Reform' Movement"); Sheryl Gay Stolberg, The Pugnacious Builder of the Business Lobby, N.Y. TIMES, June 2, 2013, at BU 1 (describing how the president of the U.S. Chamber of Commerce's "free market views" guide the chamber and shape its lobbying).

91 The market ideologies of the conservative Justices bring social consequences that parallel the social consequences promised by their recent major decisions on both voting rights and campaign finance. See supra note 79 (McCutcheon, Shelby County, and Citizens United). These decisions handicap ordinary Americans, especially the weakest and most vulnerable: they encourage in varying ways the further concentration of money and power in the hands of the nation's largest corporations and wealthiest citizens. On the growing inequality in the United States, see LARRY M. BARTELS, UNEQUAL DEMOCRACY: THE POLITICAL ECONOMY OF THE NEW GILDED AGE $288-89$ (2008) (noting the strong influence of the "ideological convictions of elected officials" on public policy). See generally JACOB S. HACKER, THE GREAT RISK SHIFT: THE NEW ECONOMIC INSECURITY AND THE DECLINE OF THE AMERICAN DREAM (2008); JACOB S. HACKER \& PAUL PIERSON, WINNER-TAKE-ALL POLITICS: HOW WASHINGTON MADE THE RICH RICHER-AND TURNED ITS BACK ON THE MIDDLE CLASS (2010). For the disproportionate political influence of wealth and its success in securing favorable public policies, see generally MARTIN GILENS, AFFLUENCE AND INFLUENCE: ECONOMIC INEQUALITY AND POLITICAL POWER IN AMERICA (2012); Benjamin I. Page, Larry M. Bartels \& Jason Seawright, Democracy and the Policy Preferences of Wealthy Americans, 11 PERSP. ON POL. 51, 66 (2013) (noting the findings of a study that found that wealthy Americans are more likely to be politically conservative).

92 See LeE EPSTEIN, William M. LANDES \& Richard A. POSNER, THE BEHaVior OF FEDERAL JUDGES: A THEORETICAL AND EMPIRICAL STUDY OF RATIONAL CHOICE $3^{85}$ (2013) (" $[\mathrm{I}]$ deology influences judicial decisions at all levels of the federal judiciary."). Although the jurisprudence of the Rehnquist and Roberts Courts is the product of varied factors and encompasses different shifts and emphases, ideology has been a critical driving force in shaping its social imperatives and doctrinal interpretations. See, e.g., Burbank \& Farhang, supra note 55 , at 1569 (noting that research on these courts "assumes that the phenomenon in question is a manifestation of the ideological preference of an increasingly conservative Supreme Court"); Stone, supra note 78 , at 89 (noting that the decisions of conservative Justices Rehnquist, Roberts, 
The majority of the Justices on the Rehnquist and Roberts Courts are conservative Republicans who share, with varying shadings, their party's ideological views and values. ${ }^{93}$ Indeed, prior to ascending to the high bench, five of the Justices held high-level positions in Republican administrations. ${ }^{94}$ Moreover, all were selected by Republican presidents and supported virtually unanimously by Republican senators seeking assiduously to create a Court that would reflect their party's views. ${ }^{95} \mathrm{With}$ respect to the values of market ideologies and the goals of "tort reform," they largely succeeded. ${ }^{96}$

and others "were determined first and foremost by their own policy preferences"); Stephen N. Subrin \& Thomas O. Main, The Fourth Era of American Civil Procedure, 162 U. PA. L. REV. 1839 (2014).

93 "A judge who is a 'strict constructionist' in constitutional matters[,]" Rehnquist wrote when advising the Nixon administration on Supreme Court nominations, "will generally not be favorably inclined toward claims of either criminal defendants or civil rights plaintiffs." JOHN W. DEAN, THE REHNQUIST CHOICE: THE UNTOLD STORY OF THE NIXON APPOINTMENT THAT REDEFINED THE SUPREME COURT 16 (2001). John Dean, Nixon's White House counsel, confirmed that Rehnquist's statement was "a very accurate description of what Nixon wanted" in his Court appointees. Id. In Crawford-El v. Britton, two of the Court's most ideologically driven conservatives rejected the legitimacy of Monroe v. Pape, 365 U.S. 167 (1961), a foundation of modern civil rights enforcement actions under 42 U.S.C. $\$ 1983$. Crawford-El v. Britton, 523 U.S. 574,611 (1998) (Scalia, J., joined by Thomas, J., dissenting).

94 See Michael C. Dorf, Does Federal Executive Branch Experience Explain Why Some Republican Supreme Court Justices 'Evolve' and Others Don't?, 1 HARV. L. \& POL'Y REV. 457, 460-61 (2007) (recounting the political backgrounds of Justices Rehnquist, Scalia, Thomas, Roberts, and Alito).

95 E.g., TOOBIN, supra note 51, at 338; TUSHNET, supra note 54 , at $47-48$; see also HENRY J. abraham, Justices, Presidents, and Senators: A History of The U.S. Supreme COURT APPOINTMENTS FROM WASHINGTON TO CLINTON 48 (rev. ed. 1999) ("It is an unwritten law of the judicial nominating process that the president will not normally select an individual from the ranks of the political opposition."); LEE EPSTEIN \& JEFFREY A. SEGAL, ADVICE AND CONSENT: THE POLITICS OF JUDICIAL APPOINTMENTS 120 (2005) (explaining the assumption that "presidents can influence the direction of legal policy... by placing politically like-minded individuals on the bench"); NANCY SCHERER, SCORING POINTS: POLITICIANS, ACTIVISTS, AND THE LOWER FEDERAL COURT APPOINTMENT PROCESS 116-21 (2005) (explaining how interest groups and political activists mobilize to influence nominations); JAMES F. SIMON, IN HIS OWN IMAGE: THE SUPREME COURT IN RICHARD NIXON'S AMERICA (1973); Lee Epstein, Jeffrey A. Segal \& Chad Westerland, The Increasing Importance of Ideology in the Nomination and Confirmation of Supreme Court Justices, 56 DRAKE L. REV. 609, 611 (2008) (noting that "Presidents typically focus on candidates most likely to advance their own political goals"); Lee Epstein, Jeffrey A. Segal, Nancy Staudt \& Rene Lindstadt, The Role of Qualifications in the Confirmation of Nominees to the U.S. Supreme Court, 32 FLA. ST. U. L. REV. 1145, 1149-53 (2005) (explaining how the confirmation process for Supreme Court justices has become increasingly politicized).

96 On Republican "law reform" policy, see supra notes 89-94 and accompanying text, and compare the Court's Rule 8 decisions with the Republican-sponsored Private Securities Litigation Reform Act of 1995, Pub. L. No. 104-67, 109 Stat. 737 (codified as amended in scattered sections of ${ }_{15}$ U.S.C.) (both similarly imposing heightened pleading requirements on plaintiffs).

Subsequently, in an apparent compromise opinion, six Justices construed the statute's heightened pleading requirement to mean that in actions under Section 10(b) of the Securities Exchange Act of 1934,15 U.S.C. $\S 78 \mathrm{j}(\mathrm{b})(2012)$, plaintiffs must plead facts supporting an inference of scienter "at 
Few recent events capture the ideological overlap between the shared social imperatives of the conservative Justices and the market ideologies of the Republican Party better than the Lilly Ledbetter case. In a paradigmatic gender-based employment discrimination suit in 2007, the five-Justice conservative bloc ruled that the short 180 -day statute of limitations applicable in equal pay suits began running on the date the employer made its initial discriminatory decision. The ruling not only denied Ledbetter's claim but also promised to bar the overwhelming majority of all such future suits. ${ }^{97}$ Two years later, after the 2008 election gave Democrats the presidency and large majorities in both houses of Congress, they enacted the Lilly Ledbetter Fair Pay Act: this act extended the statute of limitations in equal pay cases by providing that the clock begins running anew with each paycheck that reflects an employer's discriminatory decision. ${ }^{98}$ The congressional vote on the act tracked party lines almost perfectly. With near unanimity, Republicans in both the House and the Senate backed the ruling of the Court's conservative majority by opposing the measure. ${ }^{99}$

Similarly, few cases illustrate the determination of the conservative Justices to impose their anti-plaintiff policy goals better than the recent decision in American Express Co. v. Italian Colors Restaurant ${ }^{100}$ There, the five-Justice bloc upheld a contractual provision that prohibited customers from bringing an antitrust class action and compelled them not only to arbitrate their claims but to do so individually. ${ }^{101}$ The customers argued that, for individual claimants, the cost of pursuing an antitrust claim would be prohibitive and that, as a practical matter, their claims could not proceed unless they could be brought in a class form. ${ }^{102}$ Rejecting a fundamental

least as compelling as any opposing inference one could draw from the facts alleged." Tellabs, Inc. v. Makor Issues \& Rights, Ltd., 551 U.S. 308, 324 (2007). Justices Scalia and Alito concurred in the judgment and urged a more demanding standard. Tellabs, 551 U.S. at 329, 331, 333-34 (Scalia, J., and Alito, J., concurring in the judgment). Justice Stevens dissented, suggesting a less restrictive approach. Id. at 335-37 (Stevens, J., dissenting)

97 Ledbetter v. Goodyear Tire \& Rubber Co., 550 U.S. 618, 628 (2007).

98 See Lilly Ledbetter Fair Pay Act of 2009, Pub. L. No. 111-2, 123 Stat. 5 (2009) (amending scattered sections of 29 and 42 U.S.C.) ("[A] discriminatory compensation decision ... occurs each time compensation is paid ....").

99 The vote in the House was $250-177$, with only five Democrats voting against the Act and only three Republicans voting in favor. 155 CONG REC. 1671 (2009). In the Senate, the vote was sixty-one to thirty-six, with every Democrat in attendance and two Independents voting in favor; only four Republicans-the party's only four female Senators-supported the measure. 155 CONG. REC. 1400 (2009).

100133 S. Ct. 2304 (2013).

101 Id. at 2312.

$102 I d$. at 2308 . 
purpose of Rule 23 and transforming the concepts of legal rights and remedies into meaningless abstractions, the five-Justice conservative bloc dismissed the argument as irrelevant. ${ }^{103}$ The fact that an individual claim "is not worth the expense involved in proving a statutory remedy" they explained, "does not constitute the elimination of the right to pursue that remedy." 104 Thus, the majority sanctioned a contractual weapon that effectively barred from any possible forum an untold number of potentially meritorious federal statutory claims.

On a more general level, both Matsushita and Twombly illustrate the conservative majority's faith in the benevolence of the "free market" and "rational" market behavior. Both denied any "plausible" reason to think that corporate defendants could have acted in an anticompetitive manner. Both

103 Id. at 2309. The majority went so far as to declare that the Federal Arbitration Act (FAA) itself "trumps any interest in ensuring the prosecution of low-value claims." Id. at 2312 n.5. The act, it continued, "favor[s] the absence of litigation when that is the consequence of a class-action waiver, since 'its principal purpose' is the enforcement of arbitration agreements according to their terms." Id.

104 Id. at 2311. Amgen Inc. v. Connecticut Retirement Plans \& Trust Funds, 133 S. Ct. 1184 (2013), presents a revealing contrast. There, Justice Scalia dissented and urged stricter certification requirements in securities fraud class actions: "Certification of the class," he argued, "is often, if not usually, the prelude to a substantial settlement by the defendant because the costs and risks of litigating further are so high." Id. at 1206 (Scalia, J., dissenting). Noticeably, sympathizing with the defendant's plight in Amgen, he did not apply the pivotal reasoning he employed in Italian Colors to disregard the plaintiffs' plight: that, however burdensome they might be, the "costs and risks of litigating further" did not "constitute the elimination of the right to pursue" the legal options that were formally available.

There seems to be a difference, too, between the relative lack of concern for the fate of members of the proposed plaintiff class in Italian Colors and the noticeably greater concern shown for them in Wal-Mart Stores, Inc. v. Dukes, 131 S. Ct. 2541, 2558-59 (2011), where solicitude served to support a restrictive interpretation of the monetary remedies available in class actions under Rule $23(\mathrm{~b})(2)$.

The unfavorable treatment that the conservative Justices give to class action plaintiffs revealed itself similarly in the contrasting interpretations they gave to the relevant federal statutes in Concepcion and Italian Colors. In the former, they reasoned that the FAA should not be construed to allow state law to bar enforcement of some, though not all, arbitration agreements because such a construction would defeat the purpose of the arbitration statute. AT\&T Mobility LLC v. Concepcion, $131 \mathrm{~S}$. Ct. 1740, 1752-53 (2011) (holding that a state may not require procedures inconsistent with the FAA). In contrast, in Italian Colors they reasoned that the federal antitrust laws should be construed to allow arbitration agreements to bar many, though not all, antitrust actions even though that construction would defeat the purpose of the antitrust laws. $133 \mathrm{~S}$. $\mathrm{Ct}$. at 2310-12. They justified their sweeping construction of the FAA by declaring that "the act cannot be held to destroy itself." Concepcion, 131 S. Ct. at 1748 (citations omitted). They justified their shrunken construction of the antitrust laws by declaring that "[n]o legislation pursues its purposes at all costs." Italian Colors, $133 \mathrm{~S}$. Ct. at 2309 (quoting Rodriguez v. United States, 480 U.S. 522, 525-26 (1987) (per curiam)) (internal quotation marks omitted). The two statements constituted not "principles" for judicial reasoning but rationales for predetermined results. Had the Justices wished opposite results in the two cases, they could easily have switched the two statements from one opinion to the other. 
also made what was tantamount to judicial findings of fact based solely on the assumption that free market actors would not behave in an economically "irrational" - and therefore unlawful-manner. ${ }^{105}$ Consequently, both insisted that only very specific facts evidencing such behavior could possibly make contrary allegations the least bit credible.

Easing the path to summary judgment, Matsushita found an "absence of a plausible motive to enter into the alleged predatory pricing" because defendants were "presumably rational businesses." 106 Easing the corporate path to dismissal, Twombly announced that the "natural explanation" for defendants' behavior was simply "routine market conduct" and "the natural, unilateral reaction of each [defendant] intent on keeping its regional dominance." 107

The influence of market ideologies on the Rehnquist and Roberts Courts is especially striking when those assertions in Matsushita and Twombly are compared with the views of an earlier Court. "[S]ummary procedures," a different set of Justices declared in 1962, "should be used sparingly in complex antitrust litigation where motive and intent play leading roles, [and] the proof is largely in the hands of the alleged conspirators ...."108

Twombly's embrace of market ideology, moreover, proved particularly revealing when it drew on what "history teaches." 109 Not surprisingly, it selected a historical lesson that confirmed its ideological assumptions while at the same time ignoring historical lessons that challenged those assumptions. ${ }^{110}$ Most obviously, it ignored the lesson made clear only a year after the ruling in Matsushita, when a massive stock market crash exposed pervasive fraud and chicanery in the savings and loan industry. Indeed, another massive economic collapse followed Twombly itself, this one exposing pervasive fraud and chicanery in the banking, real estate, and financial

105 See generally Bell Atl. Corp. v. Twombly, 550 U.S. 544 (2007); Matsushita Elec. Indus. Co. v. Zenith Radio Corp., 475 U.S. 574 (1986).

106 Matsushita, 475 U.S. at 595; see also Eleanor M. Fox, Antitrust and Business Power (explaining the relationship between the Court's recent antitrust jurisprudence and the Chicago school philosophy, which "opposes microeconomic intervention by the government" and "presumes that markets nearly always work to keep business responsive to consumers and that government intervention (including antitrust action) nearly always obstructs markets"), in THE REHNQUIST COURT: JUDICIAL ACTIVISM ON THE RIGHT 213, 214-15 (Herman Schwartz ed., 2002).

107 Twombly, 550 U.S. at 566, 568.

108 Poller v. Columbia Broad. Sys., Inc., 368 U.S. 464, 473 (1962).

109550 U.S. at 567.

110 For background on one such important lesson, the Enron scandal, see generally BETHA-

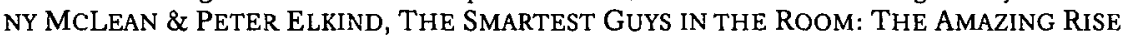
AND SCANDALOUS FALL OF ENRON (2003). 
services industries. That crash taught such an undeniable lesson that it drove another market ideologue, Alan Greenspan, into "a state of shocked disbelief" and forced him to acknowledge that his market thinking contained a fundamental "flaw."111 Large corporations and other supposedly rational economic actors could behave collusively, irrationally, and unlawfully, Greenspan reluctantly admitted, and they could do so on the broadest scale imaginable. ${ }^{112}$ The conservative Justices, however, have not acknowledged that flaw or modified their jurisprudence to reflect that vivid historical lesson.

The commitment of the conservative Justices to market ideologies is so ingrained that it revealed itself just as strongly in cases far removed from issues of economic regulation. In Town of Newton $v$. Rumery, for example, the conservative Justices upheld a plaintiff's agreement to waive his right to sue under $\S 1983$ in exchange for a prosecutor's promise not to pursue a criminal action. ${ }^{113}$ They reasoned that the agreement was voluntary, benefitted both parties, and "would not adversely affect the relevant public interests."114 Choosing to decide the case by applying "traditional common-law principles" of contract, ${ }^{115}$ they ruled that such agreements were enforceable because they were "highly rational" and not "inherently coercive." 116

Four dissenters highlighted the decisive influence of the majority's market ideology. ${ }^{117}$ The mere fact that an agreement was "voluntary" and "highly rational," they stressed, was hardly sufficient to show that it should be enforced. 118 "Otherwise, a promise to pay a state trooper $\$ 20$ for not issuing a ticket for a traffic violation, or a promise to contribute to the police department's retirement fund in exchange for the dismissal of a felony

111 The Financial Crisis and the Role of Federal Regulators: Hearing Before the H. Comm. on Oversight ES Gov't Reform, 110th Cong. 12, 46 (2008) (statement of Alan Greenspan, former Chairman, Federal Reserve Board).

112 Id. at 45-47; see also Edmund L. Andrews, Greenspan Concedes Flaws in Deregulatory Approach, N.Y. TIMES, Oct. 24, 2008, at $\mathrm{B}_{1}$ (describing Greenspan's testimony regarding his actions and the need to restrict credit default swaps to control financial markets).

113480 U.S. 386, 397-98 (1987). Justice Powell authored the majority opinion joined by Chief Justice Rehnquist and Justices White and Scalia. Id. at 388 . Justice O'Connor joined all but one part of Justice Powell's opinion, concurring separately to urge a more demanding standard for upholding such waiver agreements. Id. at 399, 402-03 (O'Connor, J., concurring). Justice Stevens dissented, joined by Justices Brennan, Marshall, and Blackmun. Id. at 403 (Stevens, J., dissenting).

114 Id. at 398 (majority opinion).

115 Id. at 392 .

116 Id. at $393-94,398$.

117 To demonstrate the influence of market ideology, the dissenters pointed to a variety of facts that should have made the agreement unenforceable but that were ignored by the majority. Id. at 410-11 (Stevens, J., dissenting).

118 Id. at 408 . 
charge, would be enforceable." ${ }^{119}$ More importantly, they insisted that the "federal policies" underlying $\S 1983$ should be given weight, ${ }^{120}$ noting that the majority placed "the interest in avoiding the expense and inconvenience of defending unmeritorious claims" above the statute's "interest in vindication of constitutional violations." 121 Finally, they pointed to the majority's "unstated premise" that $\S 1983$ suits imposed "a net burden on society."122 Given the purpose and mandate of the statute, a calculation and evaluation of its "net" social results was hardly a matter for judicial judgment. ${ }^{123}$ Indeed, as the dissenters emphasized, such a calculation could be made only by ignoring "the congressional decision to attach greater importance to the benefits associated with access to a federal remedy than to the burdens of defending these cases." 124

Discounting statutory policies and subordinating public interests to private ones, Rumery exemplifies the Court's ideologically driven decisionmaking. To reach the result the conservative Justices favored, they arbitrarily chose to rely on "traditional common-law principles" 125 instead of on the statute's substantive policy. ${ }^{126}$ That choice represented a free and unforced selection of a legal standard that promised one result over a different legal standard that supported the contrary result. ${ }^{127}$ Thus, market ideology and its anticipated social consequences ultimately directed the Court's choice of premises and guided the majority's reasoning and decisionmaking. For the conservative Justices, $\S 1983$ had no significance-legal, moral, social, political, or constitutional-other than as a possible bargaining chip in what they coldly viewed as a civil rights marketplace.

$119 \mathrm{Id}$.

120 Id. at $417-18$.

121 Id. at 419 .

122 Id.

123 See POSNER, supra note 28 , at 4 ("[I]t is even harder to estimate the benefits of our legal system than its costs. Legal rights are options that may have value even if never exercised, but how to value such options? And legal duties deter harmful conduct-but how effectively is extremely difficult to determine too.").

124 Rumery, 480 U.S. at 419 (Stevens, J., dissenting).

$125 \mathrm{Id}$. at 392 (majority opinion).

126 The conservative Justices similarly employed common law concepts to limit $\S 1983$ in Heck v. Humphrey, 512 U.S. 477 (1994).

127 The conservative Justices made a similar choice between principles in Shelby County v. Holder, 133 S. Ct. 2612 (2013), to invalidate a key provision of the Voting Rights Act of 1965 . 


\section{B. Textualism, Originalism, and Traditionalism}

The common characteristics of the Court's Federal Rules decisions and the pervasive influence of market and "tort reform" ideologies suggest troubling conclusions about the three judicial methodologies that the conservative Justices frequently invoke: textualism, originalism, and traditionalism. Although those methodologies are standard tools of judicial decisionmaking, they are frequently inadequate for any number of reasons, including their generous capacity for supporting widely varied or wholly contradictory conclusions. ${ }^{128}$ Indeed, all three concepts have been defined in differing ways to authorize widely divergent and even discordant criteria. ${ }^{129}$ The conservative Justices, moreover, have used all three methodologies in dubious and inconsistent ways. As textualists, they have interpreted language in shifting and arbitrary ways; ${ }^{130}$ as originalists, they have cherry-picked

128 For example, four of the conservative Justices supported the Defense of Marriage Act by invoking the "traditional" nature of marriage, while one of them (Justice Kennedy) voted to void the act by invoking the "traditional" power of the states to define marriage. United States v. Windsor, 133 S. Ct. 2675, 2680 (2013) (Kennedy, J.); id. at 2696 (Roberts, J., dissenting); id. at 2707-08 (Scalia, J., dissenting); id. at 2716 (Alito, J., dissenting).

129 See, e.g., JACK M. BALKIN, LIVING ORIGINALISM 129-37 (2011) (arguing that originalism and "living constitutionalism" are complementary methodologies); PHILIP BOBBITT, CONSTITUTIONAL INTERPRETATION 24 (1991) (explaining that differing "constitutional modalities" are influenced by ideology); WILLIAM M. ESKRIDGE, JR. \& JOHN FEREJOHN, A REPUBlic OF STATUTES: THE NEW AMERICAN CONSTITUTION 291-302 (2010) (noting the differing results reached by application of the same doctrines of legal interpretation to different areas of the law). See generally Stephen M. Griffin, Rebooting Originalism, 2008 U. ILL. L. REV. 1185 (discussing "new originalism" and how it differs from the originalism of the 1980s); John O. McGinnis \& Michael B. Rappaport, Original Methods Originalism: A New Theory of Interpretation and the Case Against Construction, 103 NW. U. L. REV. 751 (2009) (recognizing that the differing originalist methodologies do not have one comprehensive set of criteria). On some of the permutations of rhetorical originalism, see Thomas B. Colby, The Sacrifice of the New Originalism, 99 GEO. L.J. 713 (2011).

130 See e.g., James J. Brudney \& Corey Ditslear, Liberal Justices' Reliance on Legislative History: Principle, Strategy, and the 'Scalia Effect', 29 BERKLEY J. EMP. \& LAB. L. 117, 168-69 (2008) (noting, for example, that Justice Scalia has condemned the use of legislative history in opinions authored by liberal Justices but not in opinions authored by conservative Justices); Frank B. Cross, Essay, The Significance of Statutory Interpretive Methodologies, 82 NOTRE DAME L. REV. 1971, 2001 (2007) (arguing that textualism does not show an "effect on Court consensus" in the decisionmaking process); Eric Schnapper, Statutory Misinterpretations: A Legal Autopsy, 68 NOTRE DAME L. REV. 1095, 1101-20 (1993) (chronicling the Supreme Court's reliance on statutory interpretation and pointing out that a "variety of ideological and philosophical concerns have at times driven the Court to 'find' plain meaning in statutory language which everyone else could see full well was unclear"); Peter J. Smith, Textualism and Jurisdiction, 108 COLUM. L. REV. 1883, 1940 (2008) (illustrating and offering possible explanations for the conservative Justices' "selective application of textualist methodology to jurisdictional statutes"). "[T]he Court is more responsive to current congressional preferences than to the preferences of the enacting Congress in statutory interpretation 
sources and avoided serious historical analysis; ${ }^{131}$ and as traditionalists, they have arbitrarily conferred normative status on some practices while simply disregarding others. ${ }^{132}$

In limiting class actions, for example, the conservative Justices invoked the "historic tradition that everyone should have his own day in court." 133 They interpreted "tradition" to mean that individual plaintiffs had the right to control their own independent actions and consequently that "tradition" argued against certifying class actions. The conservative Justices, however, ignored the fact that this same "tradition" also readily supported the contrary purpose of expanding the use of class actions. Indeed, one of the "original" purposes of the 1966 amendments was to assist individuals with economically nonviable individual claims by enabling them to join together

cases." William N. Eskridge, Jr., Overriding Supreme Court Statutory Interpretation Decisions, 101 YALE L.J. 331, 397 (1991).

131 E.g., District of Columbia v. Heller, 554 U.S. 570 (2008) (holding that an individual has a constitutional right to firearm possession despite many ambiguities in the historical record and substantial evidence to the contrary); TUSHNET, supra note 54, at 148-86 (discussing the public's conception of the Second Amendment and the Court's jurisprudence on gun control); Reva Siegel, Dead or Alive: Originalism as Popular Constitutionalism in Heller, 122 HARV. L. REV. 191, 192 (2008) (arguing that the Court interpreted the Second Amendment "in accordance with the convictions of the twentieth-century gun-rights movement"); Richard A. Posner, In Defense of Looseness: The Supreme Court and Gun Control, NEW REPUBLIC, Aug. 27, 2008, at 32 ("The Court evaded the issue [of the original purpose of the Second Amendment] in Heller by cutting loose the Second Amendment from any concern with state militias ...."). Justice Alito, who regards himself as an originalist, admitted that originalism often "doesn't really decide the case." JOAN BISKUPIC,

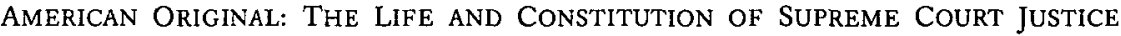
Antonin Scalia 352 (2009); see also Gordon S. WoOd, The PuRPose of THE Past: REFLECTIONS ON THE USES OF HISTORY 10-13 (2008) (arguing that "the present should not be the criterion for what we find in the past").

132 E.g., Rutan v. Republican Party of Illinois, 497 U.S. 62, 92, 95 (1990) (Scalia, J., dissenting) (arguing that the Court cannot strike down on First Amendment grounds a statute that has "the endorsement of a long tradition of open, widespread, and unchallenged use that dates back to the beginning of the Republic"); BISKUPIC, supra note 131, at 269-70 (noting that in some cases Justice Scalia argued that more than an interest in social policy was necessary to justify federal action while finding "public morality" sufficient to justify federal action in others); RICHARD A. BRISBIN, JR., JUSTICE ANTONIN SCALIA AND THE CONSERVATIVE REVIVAL 222, 327 (1997) (describing Justice Scalia's use of "tradition" to oppose liberal social policies); LAURENCE H. TRIBE \& MICHAEL C. DORF, ON READING THE CONSTITUTION 97-109 (1991) (noting Justice Scalia's reliance on "historical tradition" and arguing that such traditions are subject to manipulation). For the Court's use of "tradition" in one area of law, see Ronald J. Krotoszynski, Jr., Dumbo's Feather: An Examination and Critique of the Supreme Court's Use, Misuse, and Abuse of Tradition in Protecting Fundamental Rights, 48 WM. \& MARY L. REV. 923 (2006), and for the Court's view on "invented traditions," see Eric Hobsbawm, Introduction: Inventing Traditions, in THE INVENTION OF TRADITION 1-14 (Eric Hobsbawm \& Terence Ranger, eds., 1983).

133 Ortiz v. Fibreboard Corp., 527 U.S. 815, 846 (1999) (quoting Martin v. Wilkes, 490 U.S. $755,762(1989)$ ) (internal quotation marks omitted). 
to assert an economically viable class claim. ${ }^{134}$ Thus, in such situations class actions are essential to preserve that very "historic tradition" and ensure that everyone may secure "his own day in court."

Equally obvious, the conservative Justices ignored that very same "historic tradition" by consistently enforcing arbitration clauses in form contracts. Those decisions denied millions of individuals the possibility of pursuing their "own day in court." 135 Indeed, in their arbitration decisions, the conservative Justices accomplished a hat trick of methodological treason. They not only ignored the "historic tradition," but they also abandoned the text of the Federal Arbitration Act and rejected its "original" meaning as well. ${ }^{136}$

Thus, the conservative Justices adapted their judicial methodologies to serve their ideological purposes. That practice strengthens the inference that those same ideological purposes inspired their decisions on the three Federal Rules-decisions that were, after all, unsupported by text, original meaning, judicial precedent, or "historic tradition." Those considerations point to an even broader conclusion: in construing many other federal legal sources, the Rehnquist and Roberts Courts also likely pursued those same ideological goals. The broader significance of the Court's decisions construing Rules 8, 23, and 56, therefore, is that they suggest that those same ideological goals-not the conservatives' announced legal methodologiesshaped much or most of their jurisprudence.

134 Amchem Prod., Inc. v. Windsor, 521 U.S. 591, 617 (1997) ("While the text of Rule 23(b)(3) does not exclude from certification cases in which individual damages run high, the Advisory Committee had dominantly in mind vindication of 'the rights of groups of people who individually would be without effective strength to bring their opponents into court at all." ); FED. R. CIV. P. 23 advisory committee's note to the 1966 amendments; accord Benjamin Kaplan, $A$ Prefatory Note, 10 B.C. INDUS. \& COM. L. REV. 497, 497 (1969) ("The entire reconstruction of the Rule bespoke an intention to promote more vigorously than before the dual missions of the class-action device."); Judith Resnik, Money Matters: Judicial Market Interventions Creating Subsidies and Awarding Fees and Costs in Individual and Aggregate Litigation, 148 U. PA. L. REV. 2119, 2147 (2000) (explaining that "Rule $23(b)(3)$ was specifically designed to correct a market impediment to access and rights enforcement for certain kinds of small claims" and, as a result, "claims that never would have been pursued outside the group became viable").

135 See supra note $5^{8}$ and accompanying text.

136 See IAN R. MACNEIL, AMERICAN ARBITRATION LAW: REFORMATION, NATIONALIZATION, INTERNATIONALIZATION 148 (1992) (arguing that the Court's decisions between 1967 and 1991 "constitute a transformation of the USAA [United States Arbitration Act] worthy of the best of medieval alchemists"); see also Margaret L. Moses, Statutory Misconstruction: How the Supreme Court created a Federal Arbitration Law Never Enacted by Congress, 34 FLA. ST. U. L. REV. 99, 142 (2006) (chronicling the genesis of the FAA and the interpretive leaps that the Court has taken to reach the various outcomes it seeks); Judith Resnik, Comment, Fairmess in Numbers: $A$ Comment on AT\&T v. Concepcion, Wal-Mart v. Dukes, and Turner v. Rogers, 125 HARV. L. REV. $78,113-18$ (2011) (discussing the reach of the FAA). 
There is no principled reason why the proper construction of those three Federal Rules would bring the same practical social results as those brought by the proper construction of other federal law provisions. Yet the fact remains that the conservative Justices frequently construed a range of quite different legal sources to achieve those same congruent social results. How can this pattern of judicial decisionmaking be explained?

One possibility is that the textualist, originalist, and traditionalist methodologies of the Rehnquist and Roberts Courts revealed that all authoritative sources of federal law embodied the same practical policies. That possibility, however, defies credibility. The Constitution and the widely varied provisions of the U.S. Code were adopted and subsequently amended many times over the course of two and a quarter centuries. Those adoptions and amendments were made by diverse majorities seeking to address diverse challenges arising from the ever-changing needs of an ever-changing society. They could hardly all embody the same policies.

Indeed, it is apparent that many of those legal sources establish and seek to effectuate policies quite different from, and in conflict with, those the Court infused into its Federal Rules decisions. If textualism, originalism, and traditionalism led the conservative Justices to find that many varied federal law provisions reflected the same policies, that result would immediately reveal their methodologies as inherently flawed, easily manipulable, and ideologically inspired.

An alternate possibility is that those textualist, originalist, and traditionalist methodologies demonstrated that the policies found in some narrow subset of constitutional and statutory provisions were consistent with market ideologies and that the conservative Justices chose to interpret the three Federal Rules and other federal legal sources to conform to the policies of that particular subset. If so, however, that would mean that in construing the three Federal Rules and those other federal legal sources the conservative Justices were not guided by the methodologies they purported to employ but were, instead, guided by the policies they found in that select and narrow subset of otherwise unrelated federal law sources. If true, that would again mean that their selection of policies was directed not by their proclaimed methodologies but by personal preferences consistent with their market ideologies.

All things considered, then, the most plausible explanation for the parallel social results that mark so many of the decisions of the Rehnquist and Roberts Courts in so many areas of law is the common inspiration of market 
ideologies. ${ }^{137}$ Two conclusions seem unavoidable. One is that the proclaimed textualist, originalist, and traditionalist methodologies of the Rehnquist and Roberts Courts frequently had little or no influence on their actual decisionmaking. ${ }^{138}$ The other is that the proclaimed faith of the conservative Justices in those methodologies blinded them to the inadequacies of all three methods and thereby obscured the extent to which those inadequacies allowed their personal views to color wide swaths of federal law.

\section{Judicial Ironies and "Living" Law}

Finally, the decisions of the Rehnquist and Roberts Courts construing Rules 8,23 , and 56 point to a series of revealing ironies. The first, and most obvious, is that the ostensible goal of limiting the federal caseload-even if it were accepted as an adequate explanation for the Justices' decisionsreveals that the Court was acting pragmatically in response to practical pressures. That, in turn, would illustrate the "living" nature of law and

137 The conservative Justices did not, of course, consciously and purposely adopt "party" policies. Rather, they examined issues through the ideological preconceptions and assumptions shared with most of their fellow Republicans. Those principles are so deeply embedded that their influence may have remained largely undetected while their promptings seemed nothing but "natural" and logical premises and conclusions. What has been called "motivated reasoning" shapes judicial decisionmaking, but it does so in varying degrees with its strongest influence on relatively open and contested issues. See Stephen A. Siegel, The Constitution on Trial: Article III's Jury Trial Provision, Originalism, and the Problem of Motivated Reasoning, 52 SANTA ClARA L. REV. 373, 44352 (2012) (discussing the impact of societal influence and "motivated reasoning" on constitutional decisionmaking).

138 Indeed, their ideological imperatives seemed to determine their thinking even on relatively technical issues of actual market theory. In 1988, the Court adopted one aspect of market theorythe "efficient market" hypothesis-to make it easier for plaintiffs to assert securities fraud claims. See Basic Inc. v. Levinson, 485 U.S. 224, 248-50 (1988). In Amgen, Inc. v. Conn. Ret. Plans E Trust Funds, 133 S. Ct. 1184, 1203-04 (2013), where the Court refused to raise the requirements for certifying a Rule 23 (b)(3) class action, four of the conservatives wrote separately to urge reconsideration of the merits and use of that theory. Alito suggested that the "efficient markets" theory may rest on a "faulty economic premise," id. at 1204 (Alito, J., concurring); Scalia declared the Court's use of the theory "regrettable" and responsible for "unquestionably disastrous" consequences, id.at 1206 (Scalia, J., dissenting); and Thomas (joined by Kennedy and, in relevant part, by Scalia) declared that the Basic Court's use of the efficient market theory was "questionable" and suggested that it be reconsidered, id. at 1208 n.4 (Thomas, J., dissenting). Market theories that aided plaintiffs, in other words, should be discarded.

Similarly, in $A T E^{3} T$ Mobility $L L C$ v. Concepcion, ${ }_{131} \mathrm{~S}$. Ct. 1740 (2011), where the conservative Justices ruled that consumer adhesion contracts requiring waiver of the right to use class action forms were enforceable as written, they casually dispensed with the fact that there had been no meaningful "market" bargaining: they noted simply that "the times in which consumer contracts were anything other than adhesive are long past." Id. at $175^{\circ}$. When the assumption of "rational" economic bargaining that undergirds market theory could be used to aid plaintiffs, it too should be discarded. 
demonstrate that textualism, originalism, and traditionalism often provide inadequate, irrelevant, and easily dismissible guides.

A second irony is that originalism and traditionalism fit awkwardly with the unrestrained corporate behavior that the market ideologies of the conservative majority encourage. Free market capitalism spawns a social and economic dynamic that challenges established practices and brings constant and often highly disruptive social changes. Over the centuries it has transformed and continues to transform the world, discarding or reshaping inherited behavior patterns while spurring new and diverse practices in their place. The result is a relentless process of remolding and recreating traditions and a steady withering of the ability of each succeeding generation to accurately understand whatever "original meanings" might actually have existed and might otherwise have been discernible and applicable. That process disrupts and recreates "traditions," and it renders any such original meanings increasingly less knowable, reliable, and specific. Thus, it makes contemporary claims about the purported existence and legal significance of proposed "traditions" and "original" meanings increasingly dubious and unpersuasive.

A third irony is that those dynamic social processes illustrate the classic, if paradoxical, function of "originalist" reasoning. ${ }^{139}$ Normative appeals to ancient ideals, venerable texts, or vanished "golden ages" are designed to indict the values and practices of the present, and they are consequently anything but "conservative." They are, in fact, disruptive and even radical. Despite rhetoric to the contrary, originalism functions in practice not as a guide for an actual return to some earlier and truer legal regime-a practical impossibility in most, if not all, cases-but as a technique to undermine the status quo and install some novel regime. ${ }^{140}$

The final irony is that contemporary ideological originalism turns out to be an effective, if covert, method of developing a "living" law and "living" constitutionalism. In spite of the sharp contrast in contemporary debates between advocates of "originalism" and "living constitutionalism,"141 both

139 Alfred H. Kelly, Clio and the Court: An Illicit Love Affair, 1965 SUP. CT. REV. 119, 121-22 (showing that appeals to "history" are a method of justifying constitutional change); accord RICHARD A. POSNER, THE ECONOMICS OF JUSTICE 25-26 (1983) (arguing that although the Supreme Court Justices claim to be applying the intentions of the Framers of the Constitution, "in the hands of the modern judge, the Constitution of 1787 is an essentially fictive construct").

140 "And the older the bedrock," Judge Richard Posner noted, "the greater the scope for manipulation of meaning in the name of historical reconstruction." POSNER, supra note 28 , at 104.

141 Compare David STRAuSS, THE Living CONSTITUTION (2010) (elaborating the argument that the Constitution's meaning does, must, and should evolve), with GARY L. MCDOWELL, THE LANGUAGE OF LAW AND THE FOUNDATIONS OF AMERICAN CONSTITUTIONALISM 
approaches are methods of shaping and justifying constitutional change. Indeed, the contemporary ideological "originalism" of the Republican Party is itself, like so many earlier constitutional rhetorics in the nation's history, simply a product of historical context, political conflict, and the ordinary practice of American constitutional debate. It was inspired and energized by a political determination to overthrow the Court's post-New Deal decisions, and it was quickly embraced by those who assumed that the Founders could not have supported the modern developments they opposed: gay rights, income taxes, secularism, labor unionism, racial equality, women's liberation, affirmative action, social welfare programs, environmental protection, antidiscrimination laws, and extensive federal regulation of the economy. It was embraced, in other words, by those who found the rhetoric and values of market ideologies politically, socially, and economically attractive or at least useful for their purposes. Ultimately, then, the principal difference between contemporary ideological "originalism" and "living constitutionalism" lies only in the formalities each employs and the substantive values their advocates design them to serve. ${ }^{142}$

\section{CONCLUSION}

In construing Federal Rules 8, 23, and 56, the "expensive delicate ship"143 of the Rehnquist and Roberts Courts exposed the intensely ideological bases of their jurisprudence and demonstrated the "living" nature of the law. Indeed, the Roberts Court pushed those ideological imperatives into the realm of the Federal Rules far more extensively and vigorously than the Rehnquist Court, suggesting that the current conservative majority has grown even more active and extreme in its determination to infuse into the law the policies embedded in its market ideologies. ${ }^{144}$ Although the conservative

(2010) (defending the claim that the Constitution can be understood and properly applied only by enforcing its original meaning).

142 "Originalism is not an analytic method; it is a thetoric that can be used to support any result a judge wants to reach." RICHARD A. POSNER, OVERCOMING LAW 251 (1995). Even Robert Bork, a self-proclaimed originalist, admitted as much: "History and tradition are very capacious suitcases," he explained, "and a judge may find a good deal pleasing to himself packed into them, if only because he has packed the bags himself." ROBERT H. BORK, THE TEMPTING OF AMERICA: THE POLITICAL SEDUCTION OF THE LAW 119 (1990).

143 W.H. Auden, Musée Des Beaux Arts, in ColleCted POEMS 179, 179 (Edward Mendelson ed., 1991).

144 See Burbank and Farhang, supra note 55, at 1605-06. The view of Justice John M. Harlan, the Court's leading and highly respected conservative Justice, in Bivens v. Six Unknown Named Agents of Federal Bureau of Narcotics, 403 U.S. 388 (1971), demonstrates the radical change since the 1980 in what has become judicial "conservatism": "I simply cannot agree with my Brother Black 
Justices on both Courts proclaimed adherence to judicial methodologies that supposedly ensured their legal "objectivity," they steadily and methodically remade the law to serve the substantive policies and partisan values of the contemporary Republican "conservatism" from which they sprang. ${ }^{145}$

that the possibility of 'frivolous' claims-if defined simply as claims with no legal merit-warrants closing the courthouse doors to people" who claim that their constitutional rights have been violated. Id. at 410 (Harlan, J., concurring in the judgment).

145 On the persistent disjunction between methodological assertions and judicial judgments, see, for example, James B. Staab, The Tenth Amendment and Justice Scalia's "Split Personality," 16 J.L. \& POL. 231, 378 (2000) (arguing that Scalia "is not the neutral robot he sometimes portrays himself to be[;]" instead, "[h]is opinions ... are attempts by him to reach desirable results"); Stone, supra note 78 , at 88 (arguing that "the voting behavior of the very conservative justices cannot be explained by any commitment to the principal of judicial restraint"); Richard A. Posner, The Spirit Killeth, but the Letter Giveth Life, NEW REPUBLIC, Sept. 13, 2012, at 18, 23 (reviewing ANTONIN SCALIA \& BRYAN A. GARNER, READING LAW: THE INTERPRETATION OF LEGAL TEXTS (2012)) (illustrating the "remarkable elasticity of Scalia and Garner's [originalist] methodology"). 
